\title{
Thermal Tourism and Geoheritage: Examining Visitor Motivations and Perceptions
}

\author{
Anna Chrobak ${ }^{1, *(0)}$, Francesca Ugolini ${ }^{2}$, David Pearlmutter ${ }^{2,3}$ and Antonio Raschi ${ }^{2}$ \\ 1 Institute of Geography, Pedagogical University of Kracow, ul. Podchorążych 2, 30-084 Kraków, Poland \\ 2 Institute of BioEconomy, Italian National Research Council, via Madonna del Piano 10, 50019 Sesto \\ Fiorentino, Italy; francesca.ugolini@ibe.cnr.it (F.U.); davidp@bgu.ac.il (D.P.); antonio.raschi@ibe.cnr.it (A.R.) \\ 3 Department of Geography, Ben-Gurion University of the Negev, P.O. Box 653, Beer-Sheva 84105, Israel \\ * Correspondence: anna.chrobak@up.krakow.pl; Tel.: +48-509768507
}

Received: 25 March 2020; Accepted: 11 May 2020; Published: 13 May 2020

\begin{abstract}
Kúpele Vyžne Ružbachy spa and San Giovanni spa are very well known spas located in Slovakia and in Italy. Both spas are surrounded by environmental and historical richness, including geological features that hold considerable potential for geotourism. In order to gauge the promotional value of these geological features, this study investigates: (a) The motivation of tourists for visiting the area, (b) the level of visitors' interest and knowledge regarding the area's geological features, (c) their assessment of the attractiveness and accessibility of these features, (d) their overall opinion about the area for geotourism, and (e) indications for utilizing these features to improve the landscape knowledge of the general public. The data were collected using on-site survey methods and examined by statistical analysis. Results of the survey show that the attraction of tourists to these areas is due not only to health and wellness benefits, but also to social aspects and the desire for exploring new places. It was found that the geological elements in both locations hold significant geotourism potential—and efforts to increase visitors' awareness of their environmental and cultural significance could be decisive in capitalizing on the attraction of these unique sites. Improvement of the accessibility to the sites would be highly recommended as a way to increase tourism diversity.
\end{abstract}

Keywords: appreciation; landscape awareness; geotourism; geology; thermal tourism

\section{Introduction}

In recent years, due to ongoing social changes and a more stressful lifestyle, the demand for relaxation and recreation opportunities has gained prominence as an alternative to the conventional treatment of physical illness. At the same time, while many nature-based tourism locations are facing a structural economic crisis due to their limited tourism income, others that have promoted the benefits of "health and wellbeing" as part of their appeal have increased their incomes [1].

In particular, tourism facilities such as spas, which integrate thermal treatments with general wellness, are less susceptible to the effects of these recent economic challenges. For instance, in some countries, thermal tourism is increasingly linked to other forms of tourism such as sport, recreation and culture [2]. In this way, they offer the possibility of spending time outdoors and deriving benefit from the surrounding environment as well as the spa itself. One form of tourism that meshes perfectly with both thermal treatments and natural thermal features is geotourism.

Hose [3] first defined geotourism as "the provision of interpretive and service facilities to enable tourists to acquire knowledge and understanding of the geology and geomorphology of a site (including its contribution to the development of the Earth sciences) beyond the level of mere aesthetic appreciation". Several other definitions have followed [4], though all share a focus on landscape 
and geology, and on promoting knowledge and conservation of Earth features [5,6] —with some emphasizing the benefits for future generations [7].

Geotourism can intersect with other forms of tourism; in fact, there is evidence that geological features (or parks) and spas provide reciprocal aid [8] and many geosites have a positive impact on tourism development, such as in Canyon Colca Geopark in Peru [9,10], Kızılcahamam-Çamlıdere Geopark in Ankara, Turkey [11]; Krupaja and the Žagubica Springs in the Homolje region, Serbia [12], Czech-Bavarian Geopark (geopark.cz) and also in another part of Spiš Region in Slovakia [13].

Geological features tell us a story that was written over the course of millions of years, including elements of abiotic nature that were formed due to the activity of mineral and thermal waters. Some of these features are considered more beautiful and interesting than others, and their value derives not only from their unique character but also from their scientific and educational value. The question is whether these features are compelling only for visitors with a specific interest or specialized knowledge in geology [14], or also for a broad spectrum of tourists whose familiarity with Earth sciences [15] may vary widely. In our view this is a crucial distinction, because one of the central aims of geotourism is to interpret and promote the geoheritage of a particular destination by making it easily understandable and attractive, and thus accessible, to the general public. Moreover, in a context in which the main attraction is the spa, like in this study, the presence of geological features might be of secondary relevance for the users.

Another issue is that the description and promotion of new geosites generally relies on individual scientific experts, on the basis of their expertise in geology and their specialized knowledge of the territory. Decisions are often based on specific identification and qualitative assessment methods [16,17], the thus the choice to promote a geological feature as a geosite is often subjective and linked to local territorial policy decisions.

Understanding the receptiveness of tourists to the prospect of increasing their knowledge about a specific natural area (especially in terms of its geological features) would be helpful in promoting actions that aim to increase people' general geological knowledge of the territory. It could also contribute added value to the particular area, and provide valuable insights for landscape planning and protection. Therefore, such tourist-centered research may supplement existing analytical research based on traditional scientific assessment methods.

Such questions may be addressed using motivation theory, which is extensively applied in tourism studies (e.g., [18] and which may be divided into two different approaches to the understanding of human motivations [19]. The first approach is based on content theories, which investigate "what the human needs are and how these needs change over time" [20]. In contrast, the second approach is based on process theories and attempts to describe "the mechanisms by which human needs are formed and could change" [21,22]. According to Kozak \& Decrop [18], content theories have been applied in the specific context of tourist motivations by Pearce [23], Crompton [24] and Iso-Ahola and Allen [25].

The motivation of tourists to travel has been widely studied, and a variety of different theories have been developed $[18,26]$. Many of these theories are based on the assumption that tourists are driven by underlying behavioral patterns that lead them to particular types of destinations. The analysis of such psychological needs can be traced back to the hierarchy theory of Maslow [20], and subsequent theories of push and pull motivations $[27,28]$. According to these theoretical frameworks, tourists respond to "pushing" factors (such as the need to rest and escape from daily life routines) as intrinsic motivations to travel, while "pulling" factors attract them to particular destinations. Crompton [24] first identified seven pushing factors (escape, self-exploration, relaxation, prestige, regression, kinship-enhancement, and social interaction) and two cultural, or pulling factors (novelty and education). This theory has been applied in many studies concerning trips to different destinations or events [29,30].

Therefore, tourists' motivations are influenced not only by personal factors but also by the characteristics of the destinations, which in turn may be promoted in ways that respond to the expectations and desires of potential visitors. The way the information is delivered to the tourist and the way the tourist processes the information play a critical role in building the tourist's perception, 
which may differ from the "true" attributes of the touristic offering [29,31-33]. Satisfying the tourist's pre-travel expectations and maximizing actual travel satisfaction should be business objectives, and promoting the physical attributes of the destination with an objective description of its characteristics and attractiveness for tourists is necessary to enhance tourist satisfaction and destination loyalty [34].

In the current study, two "thermal tourism" sites, Kúpele Vyžne Ružbachy spa in Slovakia and San Giovanni spa in Italy, have been considered because of the combination of the thermal pools-which are assumed to be the main attraction for tourists, satisfying their intrinsic motivations related to health and relaxation-and the geological features of recognized scientific value, that are located in close proximity of the pools.

\section{Materials and Methods}

In order to gauge the true interests of such potential "geo-tourists", we used motivation theory to examine the assumption that the main motivation for tourists at thermal spas is to exploit the spa facilities themselves, rather than to explore the natural elements in their immediate vicinity. This hypothesis is tested by raising the question of whether these tourists show significant interest in geology and Earth science-related themes, and whether this interest is reflected in their actual behavior, considering the geological features they visit relative to the length of their stay (and possible lack of time or motivation) or other characteristics of their visitation.

Given the above assumptions, the main purpose of this paper is to describe the nature of tourists' attraction to geological features located near spas-based on the prevailing level of their knowledge and the diversity of their motivations, as revealed in a comparative analysis of case studies in two different countries [35,36].

In this study we applied the principles of motivation theory to examine the "pushing" and "pulling" factors that attract tourists to thermal spas, and in particular to the geological features nearby. For this purpose. we considered Crompton's [24] intrinsic motivations such as relaxation and escape from routine, exploration and self-evaluation, enhancement of kinship relationships, facilitation of social interaction, novelty, and knowledge.

Our working assumptions were (a) that visitors to the spa are mainly interested in enjoying the recreational and therapeutic aspects of the spa facilities themselves; (b) that they are mostly unaware of the presence and educational relevance of the geological elements around the spa; and (c) that they might be interested to become better acquainted with them if offered the opportunity. Hence, we hypothesized that spa tourists tend to visit these geological features only if their stay is of sufficient length, and if their awareness is enhanced through information that is easily accessible.

These hypotheses were investigated through face-to-face surveys at two thermal spa sites, asking visitors a series of questions regarding: (a) The motivation of tourists for visiting the area, (b) the level of visitors' interest and knowledge regarding the area's geological features, (c) their assessment of the attractiveness and accessibility of these features, (d) their overall opinion about the area for geotourism, and (e) indications for utilizing these features to improve the landscape knowledge of the general public.

\subsection{Description of the Two Areas}

The two "thermal tourism" sites, Kúpele Vyžne Ružbachy spa in Slovakia and San Giovanni spa in Italy, were chosen on the basis of tourism-related and environmental criteria. The two spas are firstly similar in terms of their facilities, with both offering pools with warm thermal water alongside a hotel, restaurant and bar. In addition, they are similar in terms of the presence of nearby geological elements, which are similar in number and typology and which are all at walking distance from the thermal pools (Table 1). Both areas are characterized by tectonic faults which led to the formation of hydrothermal water springs and travertine deposits, and thus the location of both spas is characterized by geological features connected to thermal water. 


\subsection{The Geographical and Geological Context of Kúpele Vyšné Ružbachy (Slovakia)}

Kúpele Vyšné Ružbachy spa was established in the 16th century, at a site which is rich in mineral and thermal springs. The site is located in the Spiš Region of northern Slovakia, in the eastern part of the Spišská Magura Range, east of the highest and best-known mountain massif in the country-the Tatra Mountains. It is situated in the Zálažný potok valley (Figure 1), on the periphery of the village of Vyšné Ružbachy. The area was already inhabited in the paleolithic period, as indicated by artifacts found in the nearby travertine quarry.

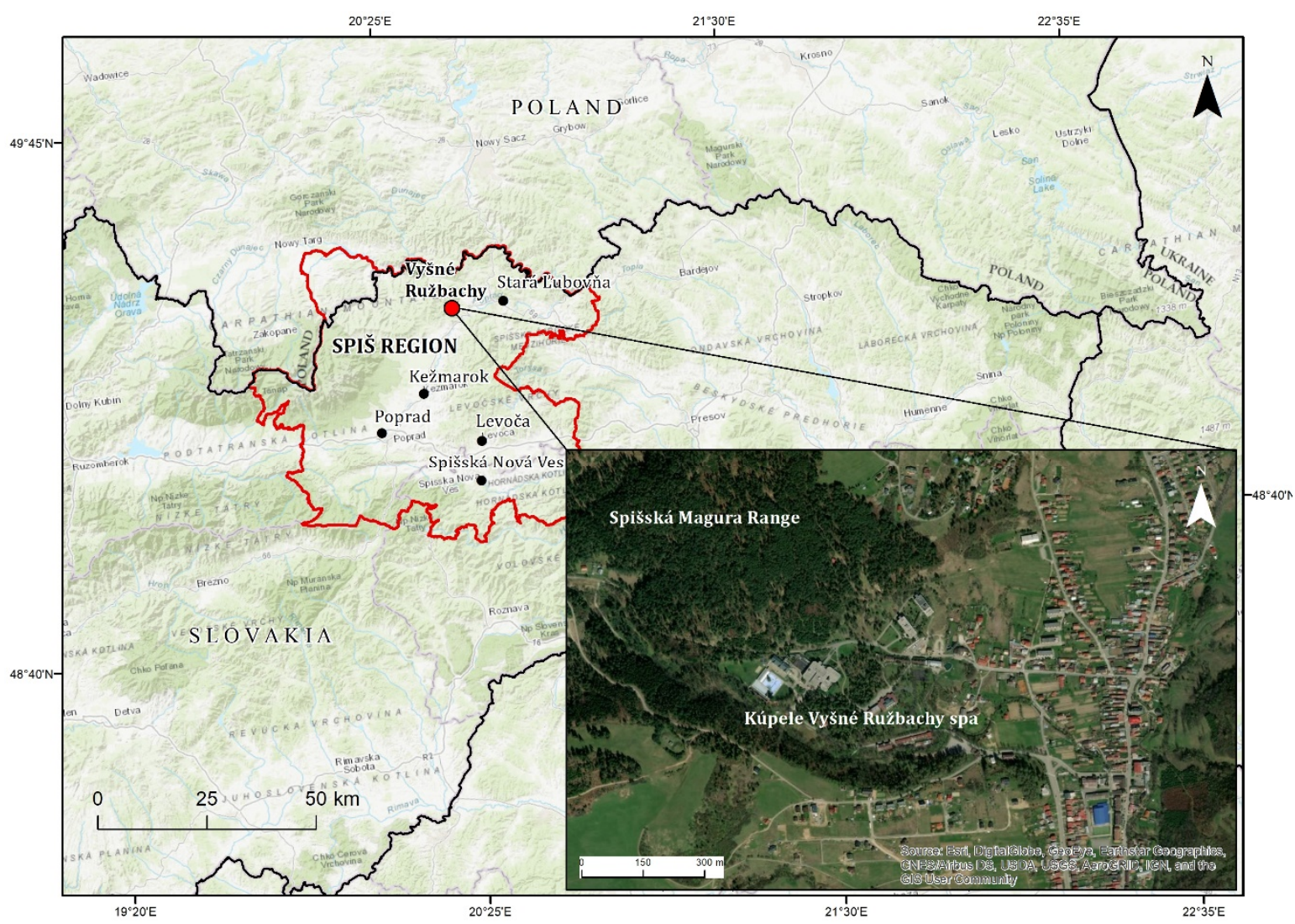

Figure 1. Location of the Kúpele Vyšné Ružbachy spa in northern Slovakia. Source: original research based on the administrative division of Slovakia, available at: geoportal.sk. Background: ArcMap basemap.

The spa itself is located near the Vyšné Ružbachy village and can be reached by car in $45 \mathrm{~min}$ from Poprad and $35 \mathrm{~min}$ from Tatranska Lomnica, the most important tourist locations for hiking in the Tatras, and 1 hour $45 \mathrm{~min}$ from Košice-the second largest city in Slovakia. It is also located close to the Polish border (30 km from the PL-SK border crossing Piwniczna Zdrój-Mníšek nad Popradom), and very close to the local road that leads directly to a national road.

The geology and geomorphological structure of the Spiš Region is extremely diverse. There are several distinct geological structures, including the Pieniny Klippen Belt, Spišská Magura Range, Kotlina Popradská Basin, Levočské Vrchy Mountains, Nízke Tatry Mountains and Kozie Chrbty Mountains [37]. In the immediate vicinity of Kúpele Vyšné Ružbachy, the most important features are geological faults-especially the Ružbachy Fault, which is responsible for the existence of mineral and thermal springs in that area and the formation of travertine deposits [38-40]. Due to the diverse geology, different geomorphological structures are present. Diverse travertine formations (craters, outcrops, quarries, caves, hills, single rocks, waterfalls, etc.) are still active and some others are passive, though both with beautiful debris and imprints of plants [41,42]. In addition, there are deep water 
valleys, gorges, landslides, caves and picturesque landscapes in the Tatra Mountains, which include the highest summits of Spišská Magura Range.

The spa is located within the foothills plant floor, which in this region is overgrown with a mixed forest consisting mainly of spruces, firs, beeches, alders and oaks. In the immediate area of the spa, birch, larch, linden and dwarf mountain pine also grow. Inactive travertine domes are covered with lichen, including among others the Rhizocarpon geographicum.

\subsection{The Geographical and Geological Context of San Giovanni Spa, in Rapolano Terme (SI, Italy)}

The area of the Siena clay lands in the Tuscany region of Italy represents a prototypical Tuscan landscape. The area belongs to an ancient lacustrine deposit, which is rich in geological features such as travertine and thermal water sources that have been exploited since Roman times for building materials (i.e., travertine stone) and for health and well-being purposes, particularly in the form of spas. The rolling hills characterizing the landscape are largely exploited for wheat production, with the exception of those areas where slope and soil erosion are the main constraints. The area is known for geomorphological features such as badlands and haddocks.

The spa (known as Terme San Giovanni) (Figure 2) is located $20 \mathrm{~min}$ by car from the city of Siena, a well-known tourist attraction in itself which is also an hour and half drive from the great renaissance city of Florence. It lies about five kilometers from a regional road and three kilometers from the closest village, Rapolano Terme. The site can also be reached by bicycle (though this is rarely done), and there is a hiking trail connecting the nearby villages. Access to the site by public transportation is extremely limited. It is located about five kilometers from a regional road and three kilometers from the closest village, Rapolano Terme.

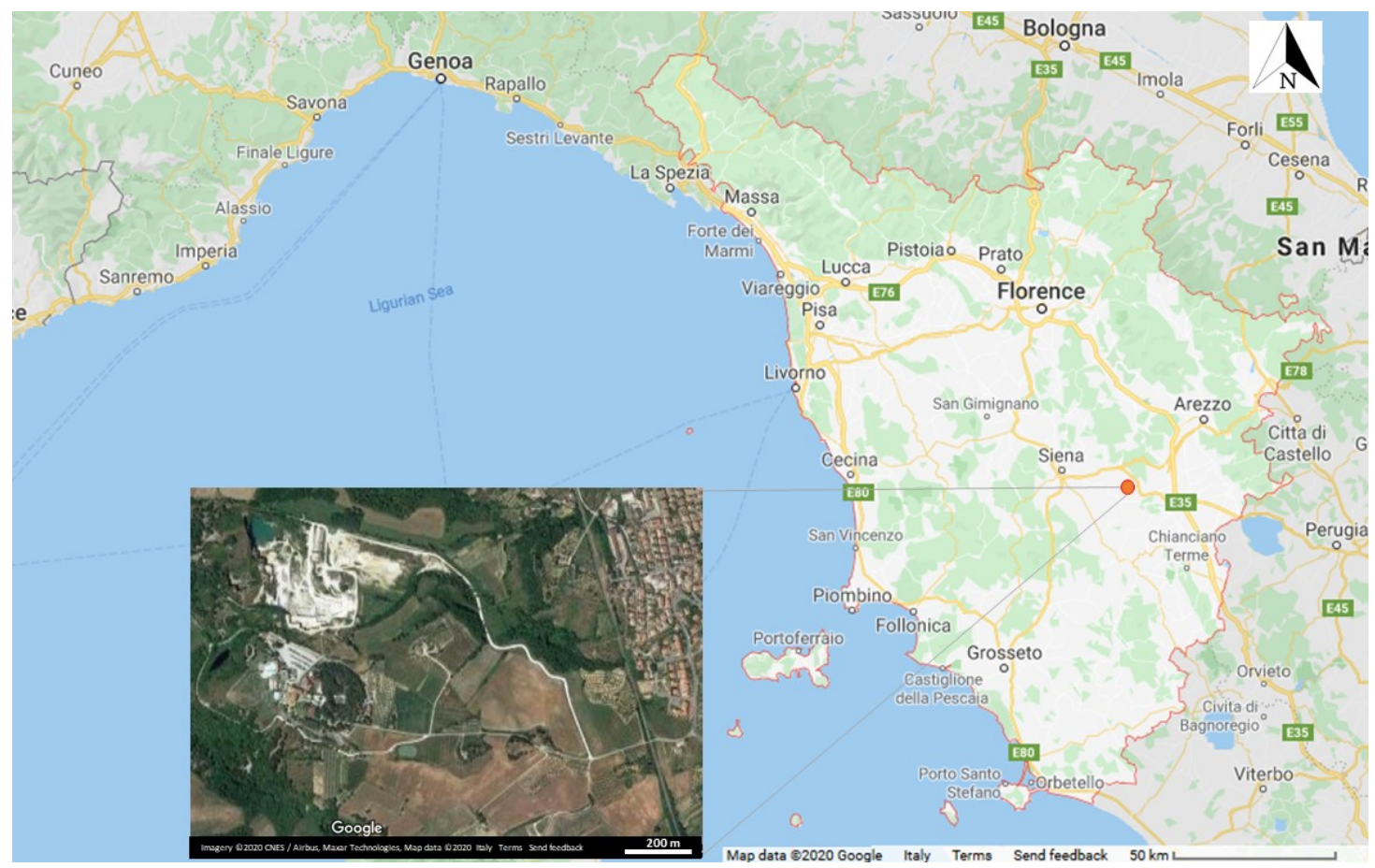

Figure 2. Map of the Tuscany region showing the location of Terme San Giovanni (indicated by red dot). Source: Google maps.

Approaching the spa, visitors cross agricultural lands and a publicly accessible park that is shaded with holm oak (Quercus ilex L.) and covered with sparse shrubs of Buxus sempervirens L. (which give their name to one the prominent geological features, the 'Bossoleto' mofette). On the opposite side of 
spa pools are views toward agricultural fields and Mediterranean deciduous forest on the steepest slopes of the landscape.

Rapolano Terme is located on the northeast border of the Siena-Radicofani basin [43], on a slope alongside the Chianti Hills and Mount Cetona [44]. An important geological feature known as the Rapolano fault, which during the Pliocene interfered with the formation of the basin $[45,46]$, runs north-south and is interrupted by smaller orthogonal faults that generated travertine deposits and thermal water springs during the Late Pleistocene [46,47], originated from ancient volcanoes formed during the Quaternary in the southern part of the area [48].

In addition to the spa itself, there are a number of distinctive natural features in the area that deserve tourist attention, and which in fact may offer an alternative cultural offering to visitors. Among the significant geological features that can be found in the surrounding area are an active travertine fissure ridge; the nearby geyser; the 'Campo Muri' archaeological site; the travertine quarry of Campo Muri [49,50]; the 'Bossoleto' mofette [51]. The active travertine fissure ridge and the Bossoleto mofette have been indicated by geologists from the University of Siena [52] as geosites of regional importance, mainly for their scientific value-but at the same time due to the risk of their degradation from local water exploitation by the nearby spa and quarry.

\subsection{Geological Elements Nearby Kúpele Vyšné Ružbachy and San Giovanni Spas}

As a first step in the case study analysis, the most important geological elements in both sites were identified (Figure 3). Table 1 presents a brief description of the features located in the vicinity of the two spas.

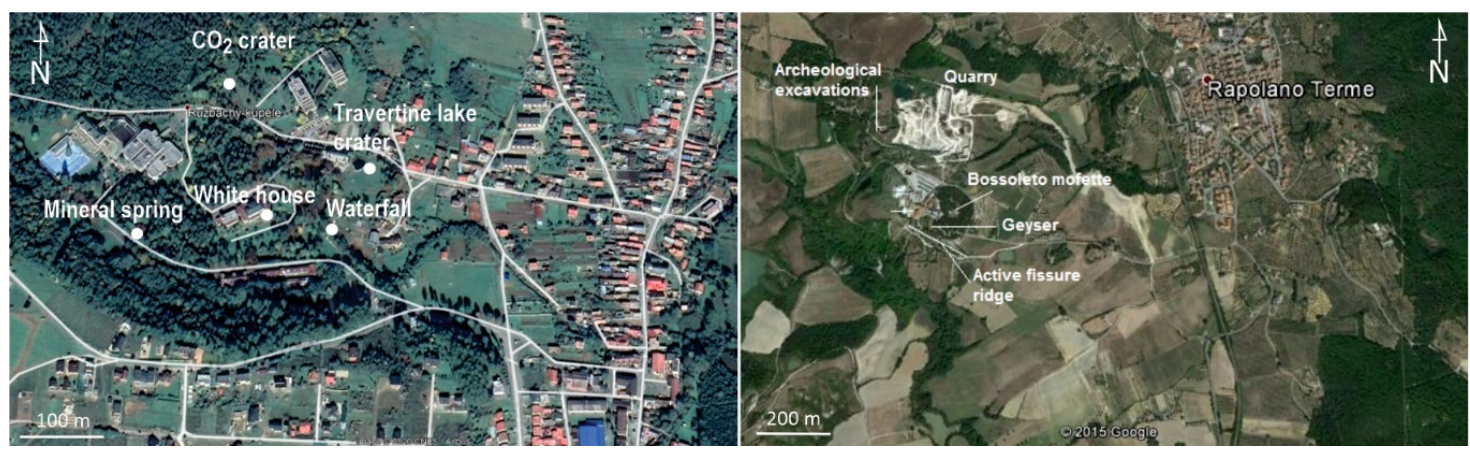

Figure 3. Map of the location of the geological features around the Kúpele Vyžne Ružbachy spa in Slovakia (left) and San Giovanni spa (right), indicated by the square. Source of the map: GoogleEarth, 2018.

\subsection{The Survey Tool}

A questionnaire (see Supplementary Materials) was custom-built for the objective of the study, containing 17 questions structured in five parts (as shown in Table 2). The first part of the questionnaire aimed to define the sample population in terms of personal details and motivations to be at the spa, as well as attitudes toward Earth knowledge and activities connected to nature exploration. The second part addressed the actual observation of geological features and landforms observed while travelling in the area. The third part focused on the assessment of the local services and local information provision, while the fourth part mostly focused on the awareness of geological features at the spa and the perception of assessment criteria such as attractiveness and accessibility. 
Table 1. Description of the geological features and points of interest in the vicinity of the two spas.

\begin{tabular}{l} 
Kúpele Vyšné Ružbachy \\
\hline Travertine Lake "Krater" (Figure 4a) \\
A unique form made of several generations of travertine [41]. The depth of the crater is $3.5 \mathrm{~m}$ and is filled with water at \\
a temperature of about $23^{\circ} \mathrm{C}$ [53]. Mineralization of the water is $2364 \mathrm{mg} /[$ [54]. It is the largest travertine lake of this \\
type in Slovakia. \\
The travertine lake "Krater" is the 'heart of the spa'. It is located next to the Krivañ guesthouse, about $80 \mathrm{~m}$ from the car \\
park located in front of the Strand Grand Hotel.
\end{tabular}

Montagnola" Fissure Ridge (Figure 5a1,a2)

San Giovanni - Rapolano Terme

a temperature of about $23^{\circ} \mathrm{C}$ [53]. Mineralization of the water is $2364 \mathrm{mg} /[$ [54]. It is the largest travertine lake of this park located in front of the Strand Grand Hotel.

"Smrtna Jama" Crater (Figure 4b)

tb) Some of the craters which were fed with occur in carbonate rocks. Water circulation sites are currently the sites of the
groundwater circulation, which often ofcen

circulation for other solutions, including $\mathrm{CO}_{2}$ and $\mathrm{H}_{2} \mathrm{~S}$ that migrate along a large fault network. In one of them $\mathrm{m}$ from the car park in front of the Strand Grand Hotel, near the bottom part of the forested valley. A path from the Hotel leads to it.

"White House" (Figure 4c)

fault line about $250 \mathrm{~m}$ long [49,50]. The longitudinal fissure varies in width from $1-2 \mathrm{~mm}$ up to $30 \mathrm{~cm}$ and in a few points, lemits water. On the smooth parts of the slope, macro and micro-carbonate terraces can be observed, together with entrance and $100 \mathrm{~m}$ from the entrance for daily tourists.

"Bossoleto Mofette" (Figure 5b1,b2)

A round-shaped doline (crater) that naturally emits $\mathrm{CO}_{2}$. Inside the doline, at a height of $1 \mathrm{~m}$ above the crater floor, $\mathrm{CO}_{2}$ concentrations can reach $80 \%$ - extremely high compared with the ambient concentration of $0.04 \%$ [50]. During the
daytime under sunny conditions, however thermal convection lowers the concentration to $0.2 \%(\sim 2000 \mathrm{ppm})$. The site

daytime under sunny conditions, however, thermal convection lowers the concentration to $0.2 \%(2000 \mathrm{ppm})$. The site

The Bossoleto mofette is located at about $100 \mathrm{~m}$ from the main entrance of the spa. It is not visible since it is surrounded by a protection wall, although a sign at the entrance door indicates the feature and its high scientific value. "Campo Muri" Archaeological Site (Figure 5c)

The most beautiful and spectacular spa hotel. It was built on the inactive travertine crater and makes use of the local travertine as a building material.

The "White House" is a well-known hotel, flagship of the spa, and is located in its central part, at $130 \mathrm{~m}$ southwest from the car park.

The Waterfall (Figure 4d)

Created on the stream flowing out of the "Krater" travertine lake. Travertine is precipitated along nearly the entire course of the stream, but most effectively it occurs on two cascades, $5 \mathrm{~m}$ and $2.5 \mathrm{~m}$ high. The amount of precipitated travertine on the cascades shows the speed and efficiency of its growth. Measurements on the upper cascade in the period from November 2008 to June 2010 [42] showed that the travertine growth rate in some places reaches $1.73 \mathrm{~mm}$ per day.

The waterfall is located at about $100 \mathrm{~m}$ Southward from the Hotel, beneath the travertine lake "Krater".

Mineral Spring (Figure 4e)

The specific location of the Kúpele Vyšné Ružbachy in the fault zone is the reason that there are about 20 mineral ascension springs [56]. The springs are fed with infiltrating water from the White Tatras area, which flows and
dissolves carbonate rocks mainly of the Middle and Upper Triassic and Eocene, from the structure of the Centrat

Carpethin Paleoget [5t]

The Mineral Spring is located in the Southern part of the spa area, at about $140 \mathrm{~m}$ Southwest from the White House.

Excavations bearing witness to Etruscan and Roman thermal baths from the 3rd century B.C. [49]. A large pool, paved with slabs of travertine, was identified as a typical Roman bath site. In the woodland nearby natural travertine channels that discharged the waters back to the river are now visible.

The archeological area belongs to the municipality and due to the lack of resources, it is generally closed to the public. It can be visited on request. The area is located at about $200 \mathrm{~m}$ from the spa and it's indicated by a road sign.

The Geyser (Figure 5d)

Located in the spa front garden, it is easily accessible to visitors. It was generated by an artesian well drilled in 1950 . Water emerges at $38-39^{\circ} \mathrm{C}$, with a flow rate of $\sim 1 \mathrm{~m}^{3} / \mathrm{min}[48]$.

The Travertine Quarry of Campo Muri (Figure 5e)

An active quarry that employs residents of the nearby villages. The travertine dates to the late Pleistocene-Holocene [60] and its extraction dates back to the medieval period.

Eltsuscan cut is also visible. However, the quarry is not accessible because it is still active. 

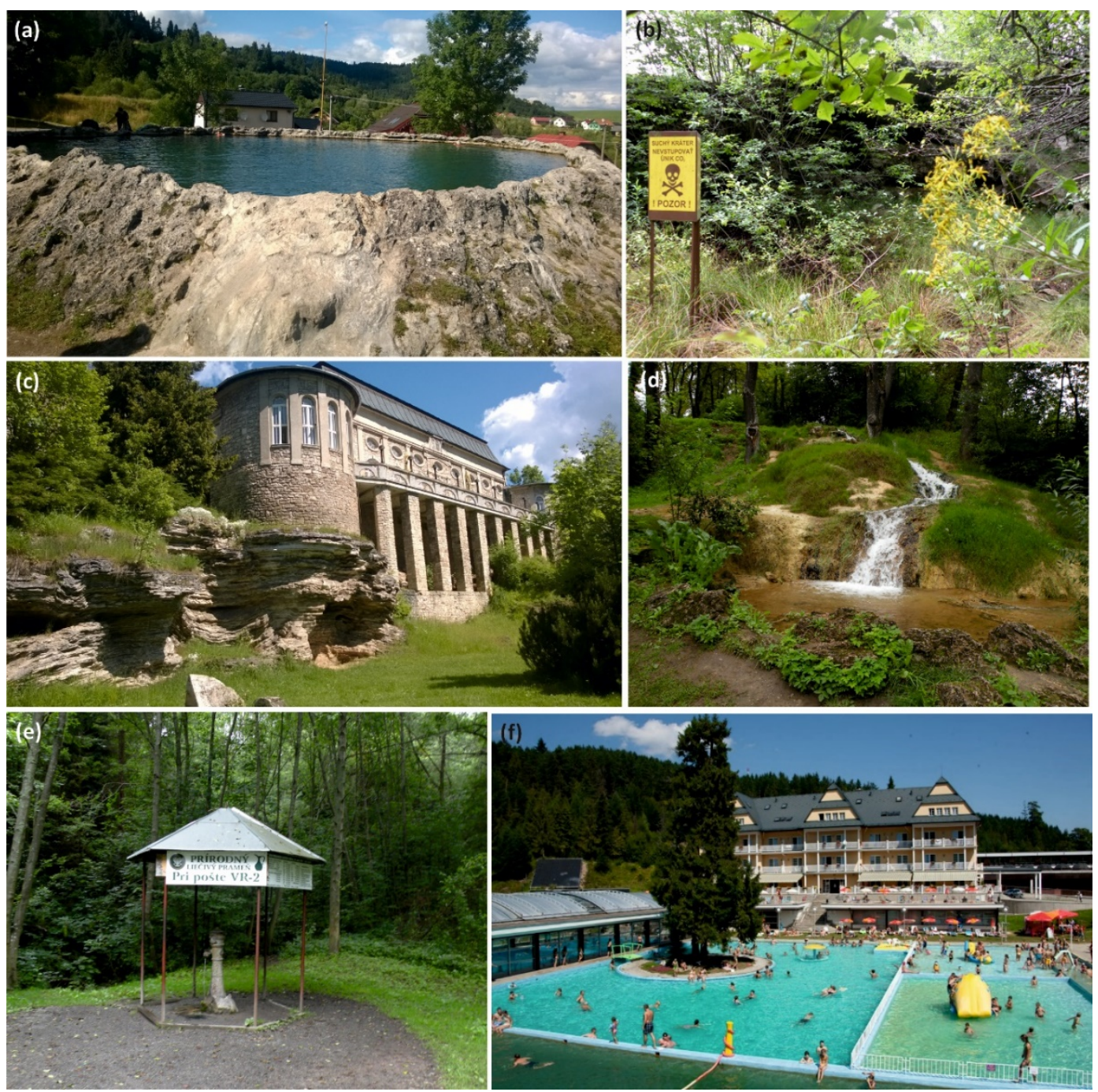

Figure 4. The geological features in Kúpele Vyšné Ružbachy spa: (a) Travertine lake "Krater", (b) "Smrtna Jama" Crater, (c) "White House", (d) The waterfall, (e) Mineral Spring, (f) External pools of the spa. Photos by A. Chrobak, http://www.ruzbachy.sk (f).

Table 2. Structure of the questionnaire.

\begin{tabular}{cc}
\hline Part & Questions \\
\hline Personal Details and Background & Gender (Q1) and age (Q2) \\
& Country and Town of residence (Q3) \\
Interest in geography and earth/landscape knowledge (Q4) \\
Accompanying travelers (Q5) \\
Length of stay (Q6) \\
Reason for staying (Q7) \\
Activities undertaken (Q8) \\
\hline Awareness of the Landscape Context & Landscape forms noticed while traveling to the site (Q9) \\
& Landscape aspects of interest (Q10) \\
\hline Awareness of Geological Features in & Features noticed around the spa (Q11) \\
the Spa Area & Attractiveness (Q12) and accessibility (Q13) of these features \\
\hline Assessment of Local Services and & Roads and public transport (Q14) \\
Information Sources & Information means used (Q15) and assessment (Q16) \\
& Suggested information means (Q17)
\end{tabular}



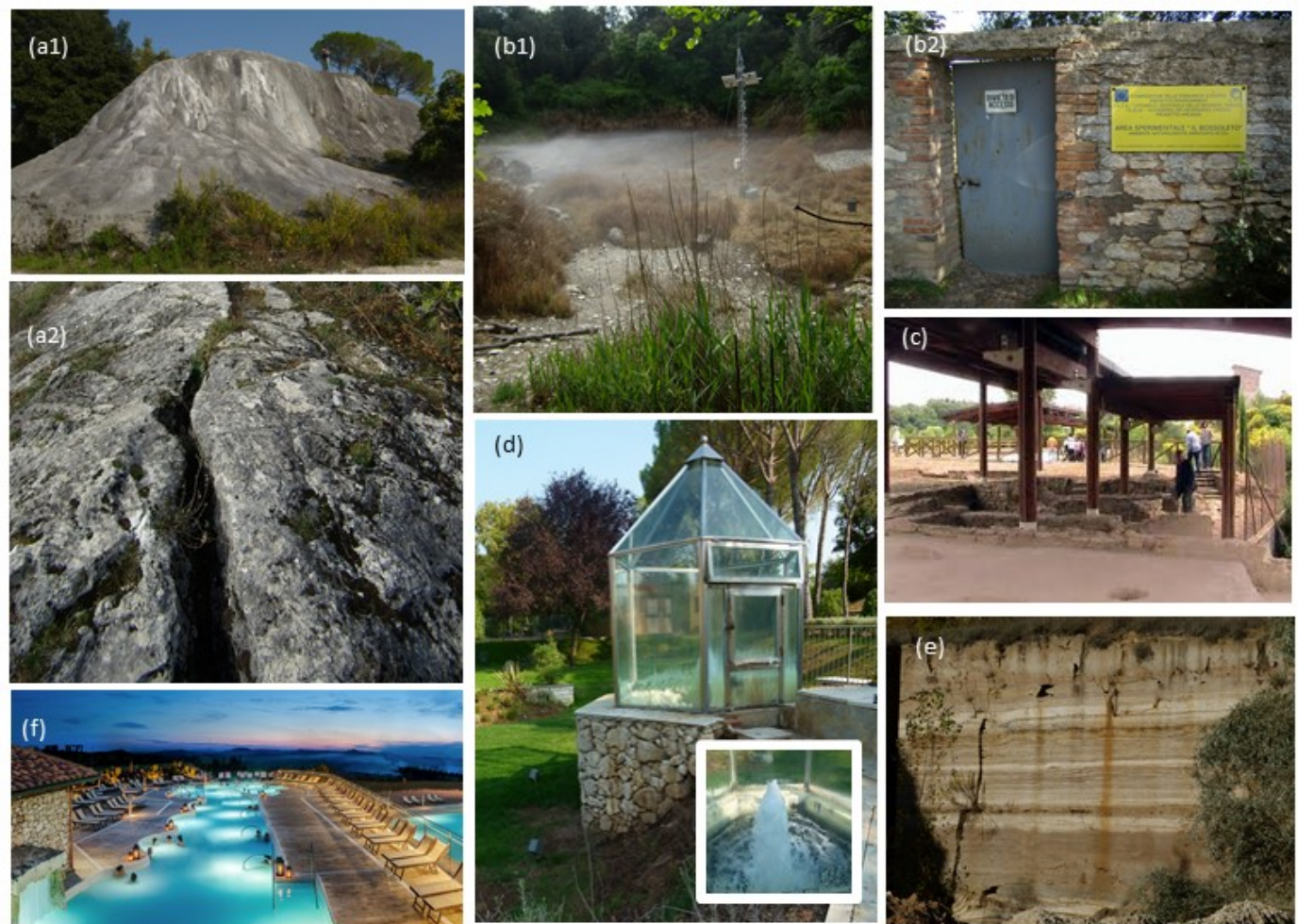

Figure 5. The geological features in the vicinity of San Giovanni spa: (a1,a2) "Montagnola" fissure ridge, (b1,b2) "Bossoleto mofette", (c) "Campo Muri" archaeological site, (d) The geyser, (e) The travertine quarry of Campo Muri, (f) External pools of the spa. Photos by F. Ugolini, http://www.sienafree.it (c), and http://www.termesangiovanni.it (f).

Administration of the questionnaire to each respondent required a personal interview about $15 \mathrm{~min}$ long. Assistance was provided in filling out the questionnaire in order to provide support regarding questions the involved specific geomorphological terms, and pictures of the geological features were provided for additional help.

Most questions were in the form of a multiple choice, with the possibility to choose one or two answers. Some of the questions (e.g., assessment of scientific/cognitive/aesthetic attractiveness, accessibility, information sources and factors important for tourism promotion) asked respondents for their level of agreement with certain statements (according to a five-point Likert scale) or the level of importance they attributed to certain features (on a four-point Likert scale).

The questionnaire was tested on a small sample of preliminary respondents (10 persons) to ensure the clarity of the posed questions, the coherence with the purpose of the questionnaire and the time needed to answer the questions. The final version was produced after correcting a few questions on the basis of initial suggestions.

\subsection{Sampling and Statistical Analysis}

While the survey was exploratory, the research was carried out using quantitative methods to minimize any subjective bias in the obtained results. Due to considerations of time and cost, the survey samples were built on the basis of the estimated prevalence of the variable of interest (setting at $80 \%$ the percentage of people interested in Earth and geography) and using an error of the estimation of $10 \%$ and a confidence level of $95 \%$. After random sampling, the precision of the estimation was confirmed by calculating the confidence interval of the sample.

The representativeness of the sample relative to the population was predicated on random sampling, which nevertheless is subject to bias due to the actual conditions on site-with practical 
limitations on the administration of the questionnaire (e.g., interviews were allowed only in specific parts of the spa).

Terme San Giovanni in Italy records approximately 30,000 visitors per year who stay at least one night, mostly members of families and groups whose average length of stay at the hotel is approximately two days (daily visitors are a larger group, numbering about four times this amount). In Slovakia, the Vyšné Ružbachy spa counts approximately 20,000 visitors a year (also who stay at least on one night). Based on analysis of the survey results and on-site observations, it is clear that a large number of additional tourists are daily visitors who rest in the spa area (e.g., around the "Krater" lake) - but since they do not use the thermal pools and therefore do not pay entrance fees, it is difficult to quantify their actual number.

The survey was prepared in the Polish and Slovak languages for tourists visiting the Vyšné Ružbachy spa, and in Italian for tourists visiting the San Giovanni spa (see Supplementary Materials). Data were collected through face-to-face interviews during the highest tourist season of August 2016 in Slovakia, and in April 2016 in Italy. Administration of the questionnaires was conducted over the course of three week days and one weekend, in order to avoid market segmentation generated by different typologies of spa tourists on weekends and weekdays [61]. Study participants were selected in a semi-random process, based on their age and willingness to respond. Respondents were approached during the hours of the day in which the spa is most frequently visited (between 10 a.m. and 4 p.m.), in the area of the bar and surrounding balconies that are open to the spa clients, without disturbing those relaxing near the pools.

The survey results were compiled in spreadsheets using Microsoft Excel (Office 2016) and a preliminary quality check was done on the completed questionnaires to filter out responses of low validity or completeness. Data were analyzed statistically using Statistica v.12 (StatSoft, Inc. 2014). The completed questionnaires were analyzed using descriptive statistics. Nonparametric equivalent of the $t$-test for the U-Mann Whitney [62] was applied to observe any difference in responses regarding travel typology (Q5-Q7) between Slovak and Italian respondents. Frequencies and percentages were calculated for all multiple choice questions (Q1-Q6; Q8-Q11; Q15, Q16) and mean scores were calculated for questions with Likert-scale selection modality (Q12-Q14; Q17), followed by a $t$-test for independent variables to observe significant differences between the average values of the items. The comparison of frequency between the responses of the two national groups was analyzed using the Chi-squared test $[63,64]$.

Correlation analysis was also performed between items treated as separate independent variables to find any relation between age $(\mathrm{Q} 2)$, travel distance $(\mathrm{Q} 3)$, traveler typology $(\mathrm{Q} 5)$, length of stay $(\mathrm{Q} 6)$ and activities (other than thermal baths) during the visit (Q8), land forms observed travelling across the clay lands (Q9) or between respondent suggestions regarding what they would like to know more about (Q10) and what they have seen around the spa (Q11).

\section{Results}

Results from each of the two surveys in the Slovakian and Italian sites are organized in five parts, according the structure of the questionnaire (see Table 2).

\subsection{Personal Details and Background}

In both spas, daily tourists represented the majority of survey respondents (and this majority is even more pronounced in the actual population of yearly visitors to the spa). In Slovakia the sample was made up of 100 respondents, $75 \%$ of whom were Slovak tourists and the remaining $25 \%$ were from Poland. Of this total, $38 \%$ were daily visitors and $62 \%$ were staying for a longer period. In Italy, the sample was made up of 71 respondents, nearly all Italian ( $98 \%)$, and mostly (47\%) daily tourists (Table 3).

Regarding age distribution, in Slovakia the largest portion (33\%) were between 46 and 65 years old, although older visitors (24\%) and youngsters below age 25 (26\%) were also well represented-indicating 
the presence of multi-generational families. In Italy, by contrast, the sample was normally distributed with most visitors (85\%) being adults between the ages of 26 and 65 .

Table 3. Descriptive characteristics of the surveyed tourists in Slovakia (SK) and in Italy (IT) in percentages $(\%)$.

\begin{tabular}{|c|c|c|c|}
\hline \multirow{2}{*}{ Question } & \multirow{2}{*}{ Option } & \multicolumn{2}{|c|}{$[\%]$} \\
\hline & & SK & IT \\
\hline \multirow{2}{*}{ Gender } & Female & 63 & 56 \\
\hline & Male & 37 & 41 \\
\hline \multirow{7}{*}{ Age } & $<25$ & 26 & 7 \\
\hline & $26-35$ & 8 & 17 \\
\hline & $36-45$ & 9 & 26 \\
\hline & $46-55$ & 17 & 32 \\
\hline & $56-65$ & 16 & 10 \\
\hline & $66-75$ & 21 & 6 \\
\hline & $>76$ & 3 & 2 \\
\hline \multirow{5}{*}{ Length of staying } & 1 day & 38 & 45 \\
\hline & 2 days & 1 & 13 \\
\hline & Less than a week & 24 & 31 \\
\hline & More than a week & 25 & 7 \\
\hline & Other & 12 & 4 \\
\hline \multirow{6}{*}{ Distance from the spa $(\mathrm{km})$} & $<50$ & 21 & 18 \\
\hline & $51-100$ & 16 & 28 \\
\hline & $101-200$ & 38 & 18 \\
\hline & $201-500$ & 22 & 32 \\
\hline & $501-1000$ & 1 & 0 \\
\hline & $>1000$ & 0 & 4 \\
\hline \multirow[t]{2}{*}{ Nationality } & $\begin{array}{c}\text { Local } \\
\text { (Slovak/Italian) }\end{array}$ & 75 & 98 \\
\hline & Other & 25 & 2 \\
\hline
\end{tabular}

A large majority of the Slovak visitors were from the eastern parts of the country, and many (38\%) were coming from large distances $(101-200 \mathrm{~km})$. The majority $(62 \%)$ were staying at the spa for longer than a single day. In Italy, nearly half $(45 \%)$ were daily visitors, though a sizable portion $(38 \%)$ were staying for more than two days. Most of the Italian tourists were from the central and northern parts of the country, with $32 \%$ coming from over $200 \mathrm{~km}$ away (Table 3).

The majority of Slovaks indicated that they were at the spa with friends $(42 \%)$ or family $(41 \%)$ while the majority of Italians were at the spa with family (55\%). When asked to rank the reasons for being at the spa (Figure 6), respondents' priority was 'to relax and rest', particularly for Italians $(p<0.000)$, along with 'escaping from routine'. Other options were also selected, with a prevalence among Italians for 'exploration of new places' (sense of wonder) $(\mathrm{p}<0.05)$ and a prevalence among Slovaks for 'meeting new people' $(\mathrm{p}<0.001)$.

Respondents were also asked about the kind of activities they engaged in during their stay (Figure 7). In the Spiš Region most reported hiking (31.6\%), while in Tuscany over $31 \%$ of respondents were engaged in excursions to town ( $\alpha<0.005$ between the two groups), with only a smaller percentage $(17.6 \%)$ reporting hiking ( $\alpha<0.05$ between the two groups). The Italian result reflects to the proximity of the spa to well-known cultural centers such as Siena and Florence.

Analyzing the frequency of responses and number of recreational activities, it was expected that the longer the stay at the spa, the more activities tourists would engage in. Referring to the results of the $\mathrm{Chi}^{2}$ test, however, it is not clear that there is a strong statistical relationship between the two variables $\left(\mathrm{Chi}^{2}\right.$ for Slovakia $=49.99 ; \mathrm{p}=0.0014 ; \mathrm{Chi}^{2}$ for Italy $\left.=37.97 ; \mathrm{p}=0.099\right)$ (Figure 8). 


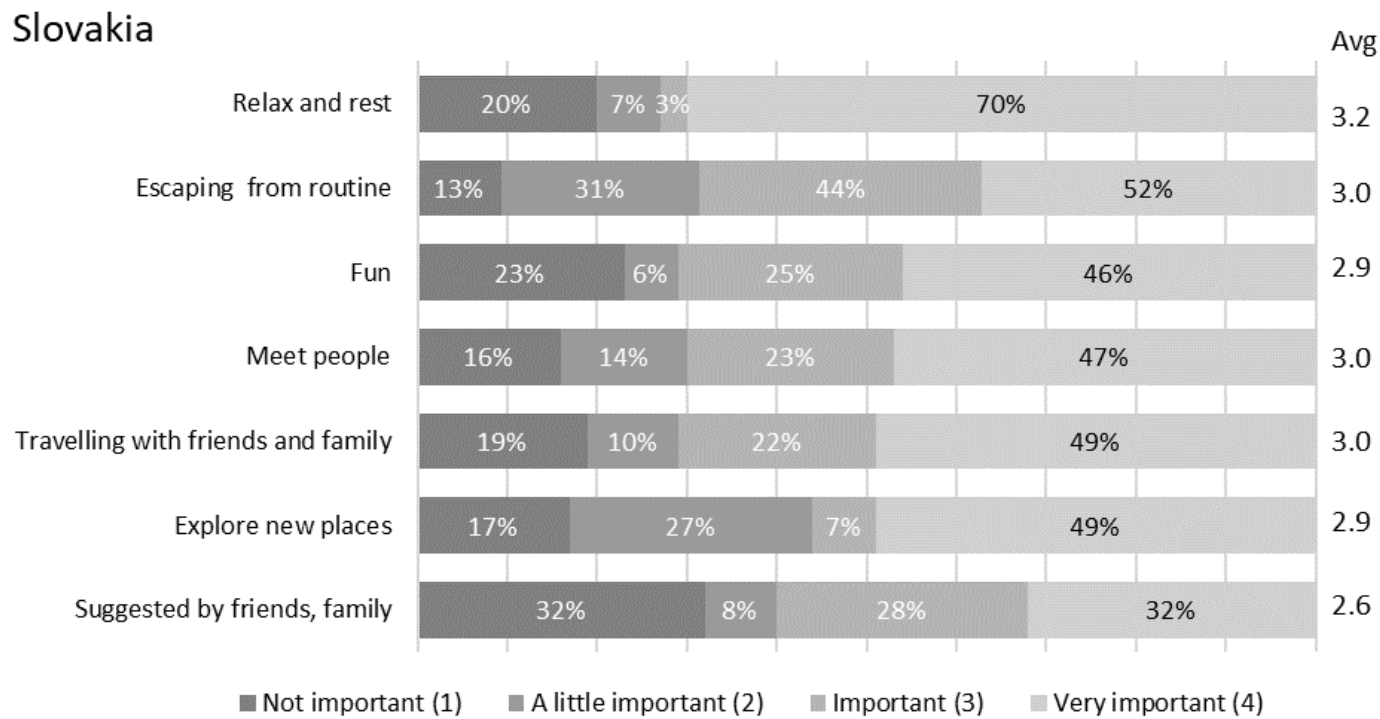

Italy

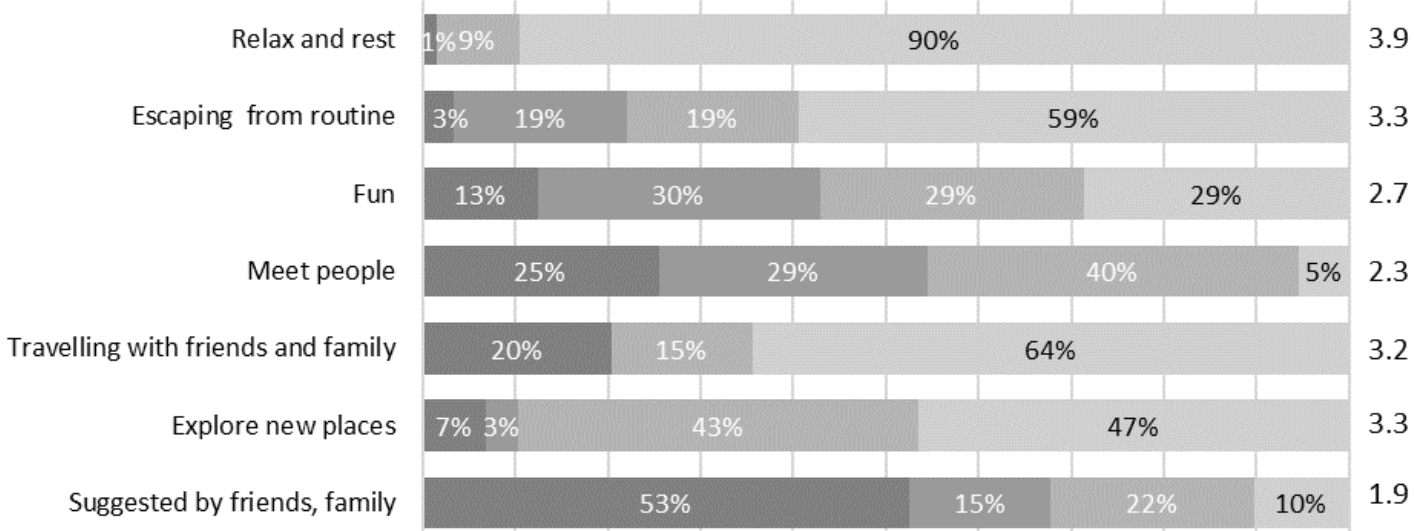

घot important (1) $\quad$ A little important (2) $\quad$ Important (3) $\square$ Very important (4)

Figure 6. Relative importance of the suggested motivations for staying at the spa in Slovakia $(\mathrm{N}=100)$ and in Italy $(\mathrm{N}=71)$. Results represent the weighted average of Likert scale values $(1=$ Not important; 2 = A little important; 3 = Important; 4 = Very important).

\subsection{Attitude Toward and Awareness of the Landscape Context}

Besides characterizing respondents in terms of their personal travel experience, we wanted to assess their attitude toward, and knowledge of, the physical landscape they were visiting. This was done firstly by asking them to assess their general interest in "Earth and geography" and their specific observations of special geomorphological features in the spa area, and secondly by inquiring as to their interest in learning more about the geo-touristic value of the territory.

A general interest in "Earth and geography" was expressed by about half the sample (49\%) in Slovakia, and by most ( $81 \%$ ) of Italian respondents. The proportion of respondents saying they were "a little interested" was 20\% in Slovakia and 15\% in Italy, while only in Slovakia did some (22\%) declare that they were not interested at all.

Respondents in each area were asked if they saw particular geomorphological and geological features in the vicinity of the spa. In both countries, many respondents naturally saw the thermal water springs ( $51 \%$ in Slovakia and $46 \%$ in Italy), though significant numbers also reported other features such as single rocks $(25 \%)$ and quarries $(12 \%)$ in Slovakia, or quarries $(23 \%)$ and badlands $(21 \%)$ in 
Italy. Other features that were not significant included gorges $(6 \%)$, landslides $(4 \%)$ and faults $(2 \%)$ in Slovakia, and haddocks (3\%) in Italy (Figure 9).
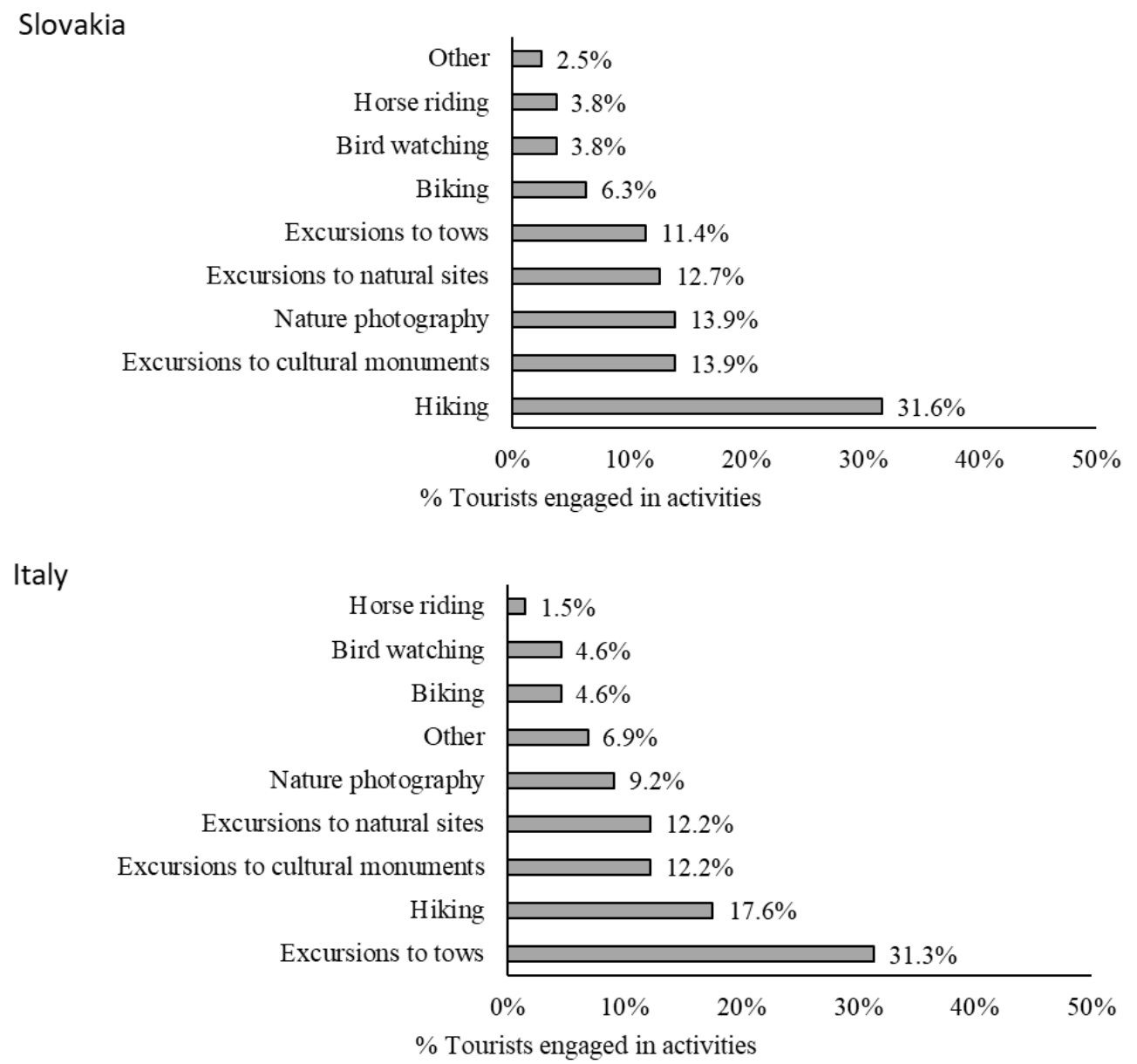

Figure 7. Percentage of responses regarding the types of activities in which the respondents were engaged during their stay in the spa in Slovakia $(\mathrm{N}=100)$ and in Italy $(\mathrm{N}=71)$. The question allowed for multiple answers.

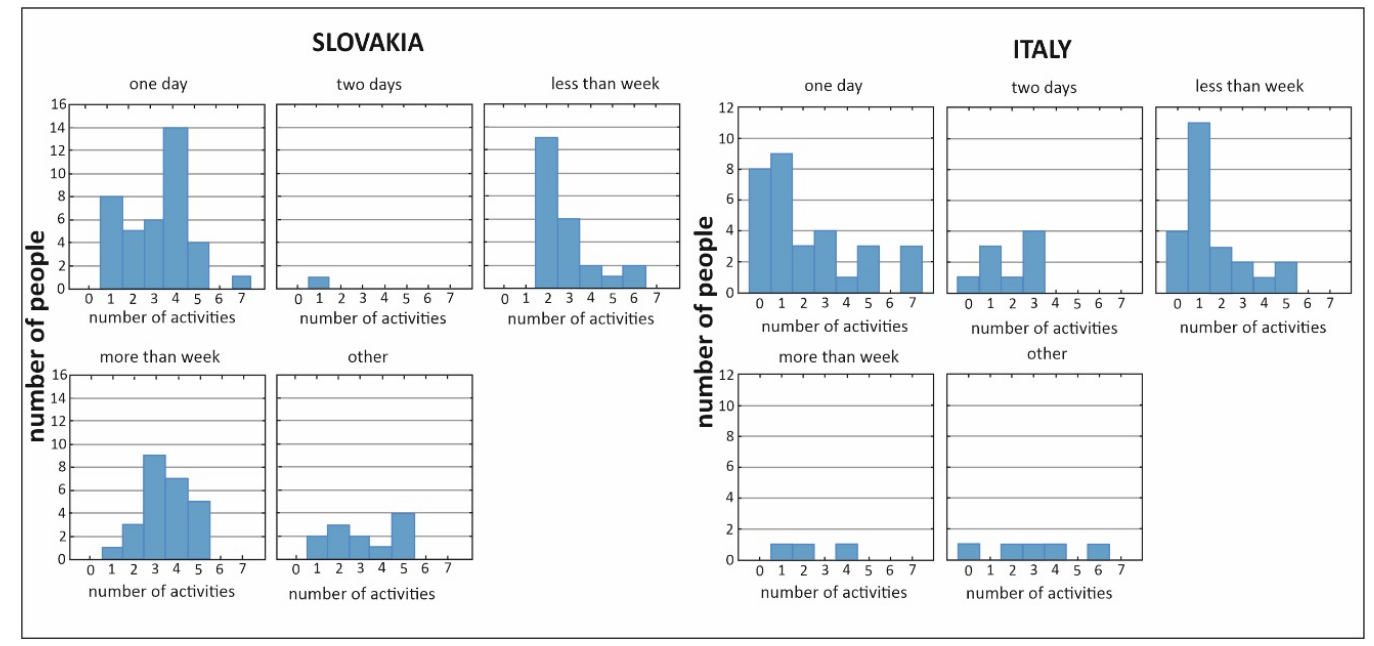

Figure 8. Frequency of responses for number of recreational activities and the length of stay in Slovakian and Italian spas. 

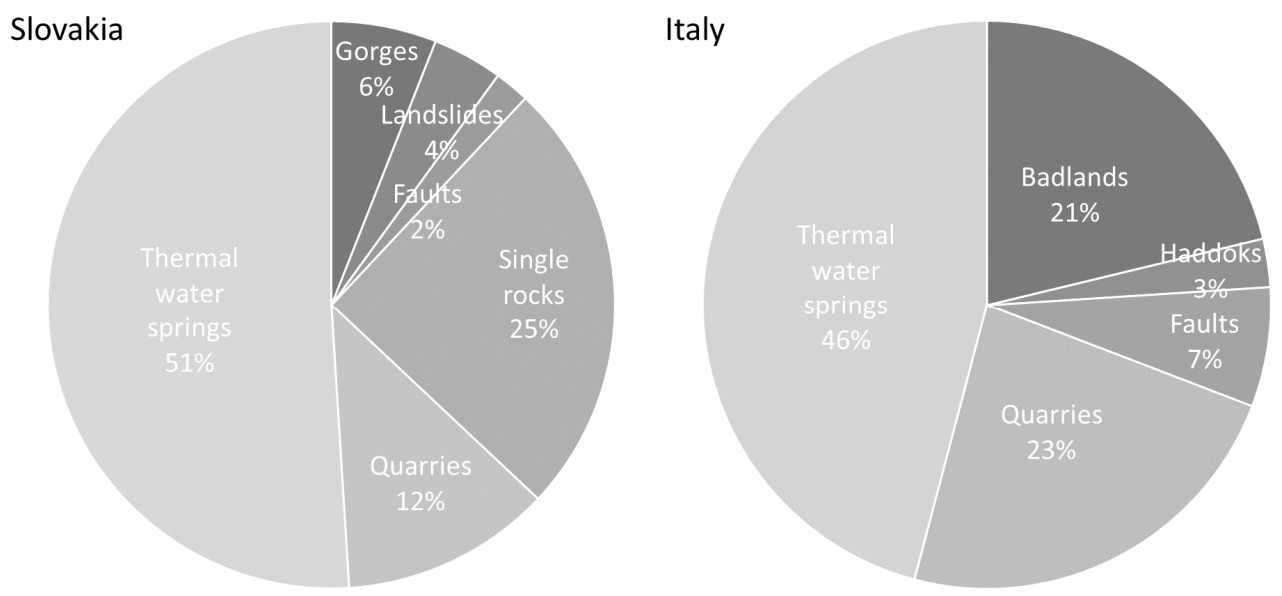

Figure 9. Percentage of selections regarding particular geomorphological and geological features that were reportedly noticed by respondents in Slovakia $(\mathrm{N}=100)$ and in Italy $(\mathrm{N}=71)$. The question allowed for multiple answers.

When respondents were asked about those aspects of the territory that they were interested in learning about, the results showed that they would appreciate knowing more about most of the aspects proposed (Figure 10)-including geology and landforms and thermal water springs, as well as the flora and fauna and the history of the region. Differences between groups were observed for food and agriculture, about which Italians traveling in Tuscany showed a particular interest $(\alpha<0.005, \alpha<0.05$ respectively) compared with those in Slovakia.
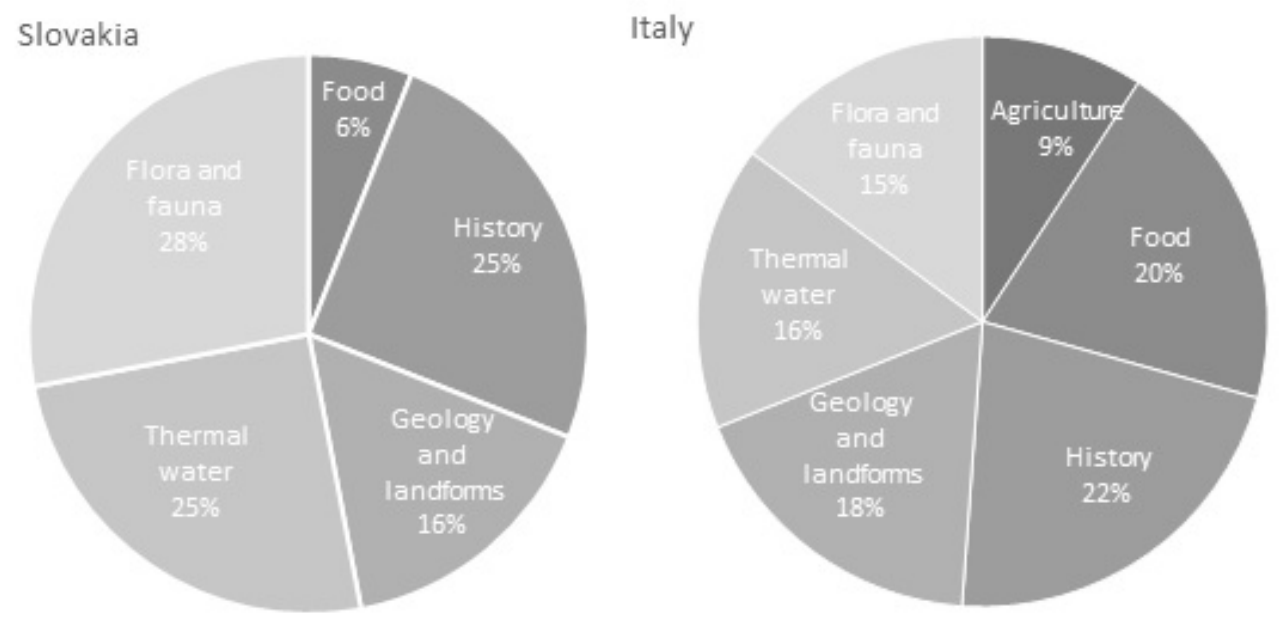

Figure 10. Percentage of responses to the question "What would you like to know more about" in Slovakia $(\mathrm{N}=100)$ and in in Italy $(\mathrm{N}=71)$. The question allowed for multiple answers.

\subsection{Awareness of Geological Features in the Spa Area}

Relating more specifically to their awareness of the natural surroundings, respondents were asked about a series of five geological features in the vicinity of the spa (see Table 1). At Kúpele Vyšné Ružbachy spa these included the Travertine lake "Krater", "Smrtna Jama" Crater with $\mathrm{CO}_{2}$ emissions, Waterfall, "White House" and Mineral Spring (Figure 4), and at San Giovanni spa the Campo Muri travertine quarry, "Bossoleto mofette", Geyser, "Montagnola" fissure ridge and Roman-Etruscan archeological excavations (Figure 5).

In Slovakia, all of the respondents reported to have seen two of the most significant geological features around the spa - Travertine lake "Krater" and "White House" - while 93\% had seen the 
Waterfall, 77\% the Mineral Spring and just 40\% the "Smrtna Jama" Crater with $\mathrm{CO}_{2}$ emissions (Figure 11).

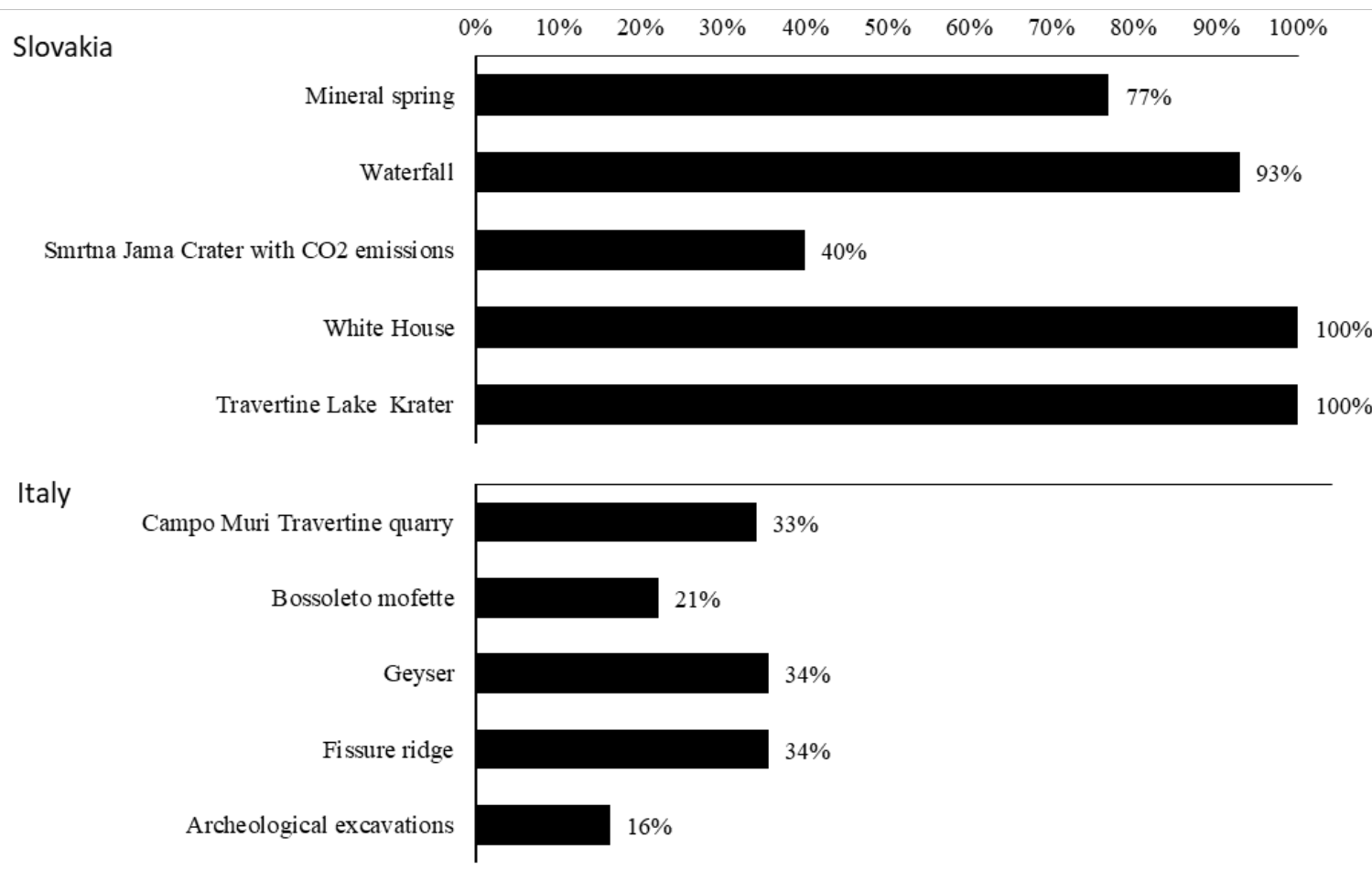

Figure 11. Slovak $(\mathrm{N}=100)$ and Italian $(\mathrm{N}=71)$ percentage of responses to the question "Which geological features have you seen around the spa?" for each geological feature.

In contrast, only a small percentage of Italian tourists confirmed that they had noticed any of the geological features in the area. The quarry, the geyser and the fissure ridge were each seen by one third of the respondents, while only $21 \%$ viewed the entrance sign of the Bossoleto mofette (the enclosed doline with $\mathrm{CO}_{2}$ natural emissions), and only $16 \%$ the archeological excavations (Figure 11).

These results might be explained by the fact that the access to the spa for daily tourists is located farther from the geological features, and none of them-even those closest to the spa-are indicated by visible signage on pathways.

An interesting connection to examine is the possible link between visitors' attention to these geological features and their self-declared interest in Earth sciences. As mentioned, only half of the respondents in Slovakia expressed such an interest, while over $80 \%$ did so in Italy. As seen in Figure 12 , however, only in Slovakia is there a positive correlation between general interest and actual visitation ( $\mathrm{p}=0.0000)$ - with increasingly large numbers of visitors who expressed an interest in Earth sciences visiting 3, 4 and 5 geological features. In Italy, conversely, there is a clear negative correlation between interest and visitation, with the largest number of those declaring an interest in Earth sciences visiting no features at all, while very few of these Italian tourists visited more than a single geological site. As discussed below, this finding alone suggests that the promotion of geotourism in this instance represents a case of missed opportunity.

The importance of promoting such features is further evidenced in Slovakia, where all respondents reported visiting the "White House" and the Travertine lake "Krater", which are highly visible and accessible, while much fewer visited the $\mathrm{CO}_{2}$ Crater which is considered hidden and hard to locate (as seen in Figure 13). It may also be seen that in Italy, about half of all respondents were not actually aware of the geological features, with at least 50\% of respondents answering "I don't know" to the question regarding their accessibility. The Bossoleto mofette was the feature most considered to be 'hidden' (which it actually is), despite the visible sign at its entrance gate. 

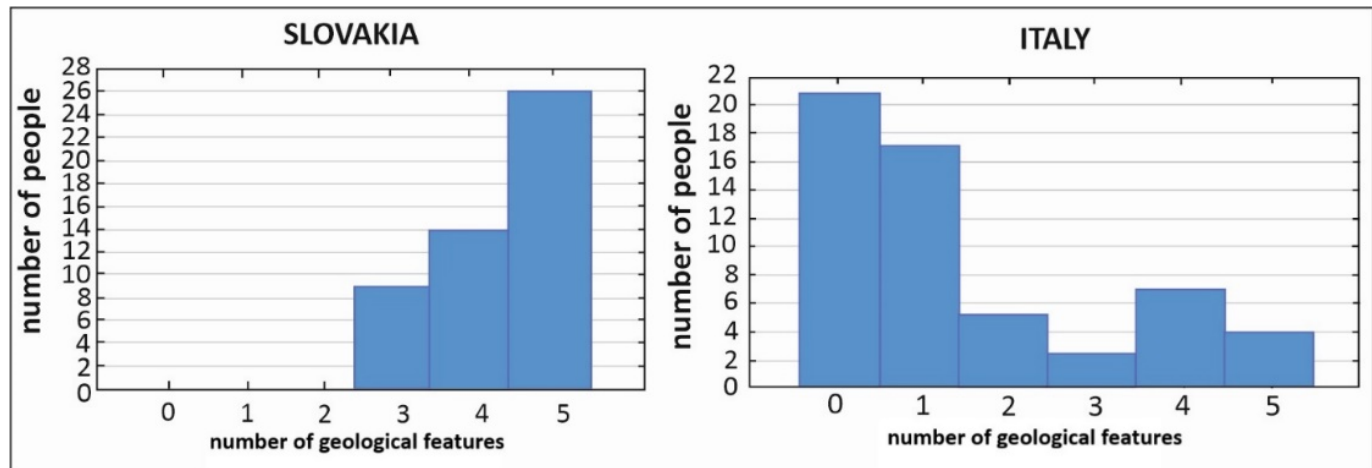

Figure 12. Distribution of the number of respondents declaring an interest in Earth sciences according to the number of geological features visited, in Slovakia and in Italy.

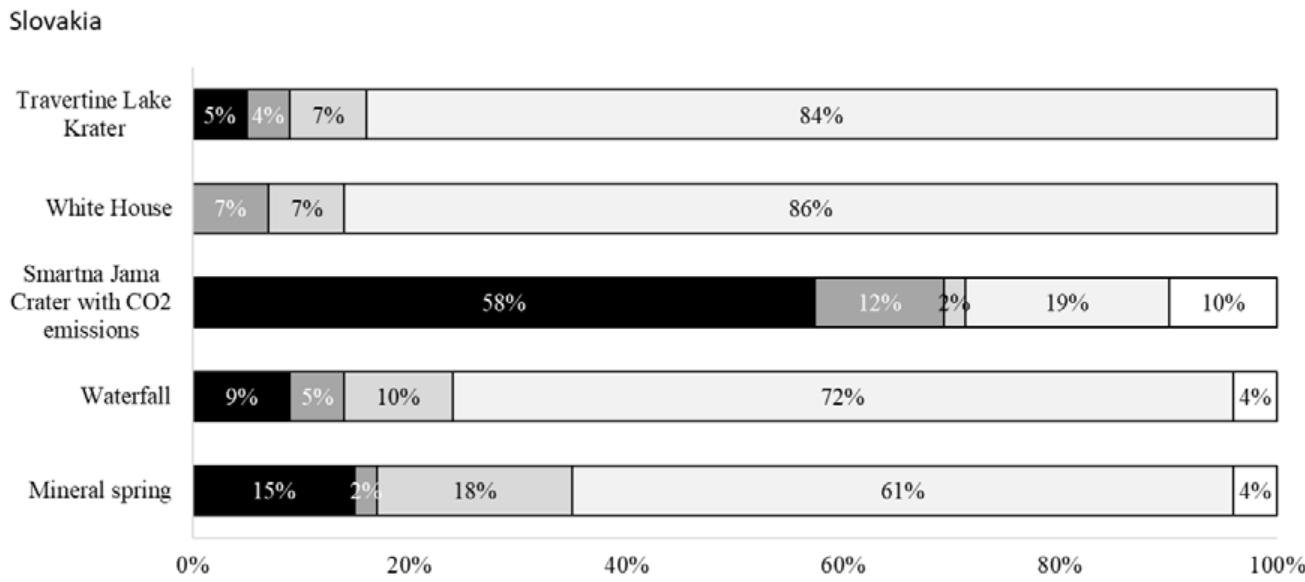

Italy

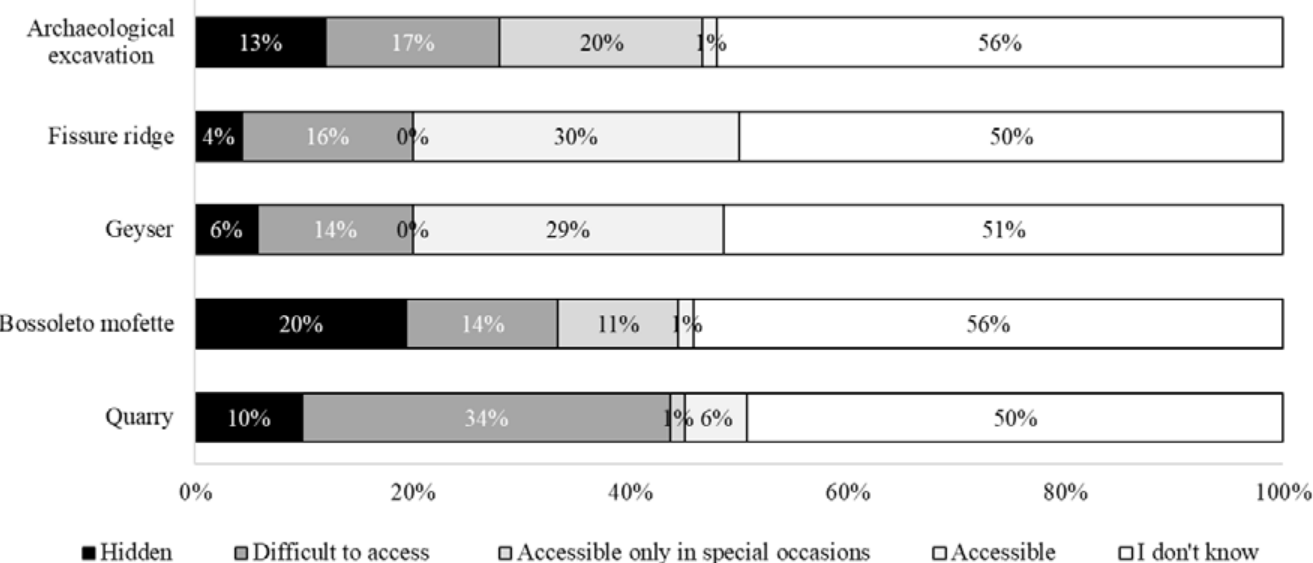

Figure 13. Perception of accessibility of geological features in Kúpele Vyšné Ružbachy in Slovakia $(\mathrm{N}=100)$ and in San Giovanni spa in Italy $(\mathrm{N}=71)$.

Campo Muri quarry was considered more difficult to access than other features, likely because there are no signs indicating how to approach it. Surprisingly, only about $30 \%$ of respondents considered the "Montagnola" fissure ridge and geyser accessible, despite the fact that these features are next to the spa entrance and freely accessible. These results further highlight the fact that the San Giovanni spa area is missing of any type of meaningful indication that would encourage visitors to reach these sites of geotouristic value. 
Regarding their interest in the geological features (Figure 14), relatively few respondents in Slovakia consider the "Smrtna Jama" $\mathrm{CO}_{2}$ Crater to be of interest to the general public, even though $25 \%$ consider it to be well known. The Travertine lake "Krater" and the "White House" are popular, while the Waterfall is well known but not highly appreciated. In Italy, a significant portion of respondents thought that features such as the archeological excavations (43\%), "Montagnola" fissure ridge (43\%) and geyser (49\%) do not match the interest of the general public, and that they are considered well known but not popular. The Bossoleto mofette and Campo Muri quarry are mainly considered (by 31\% and 36\%, respectively) to be known only to a few members of the public - and this assessment reflects the fact that they are mainly frequented by workers and researchers with specific interests.
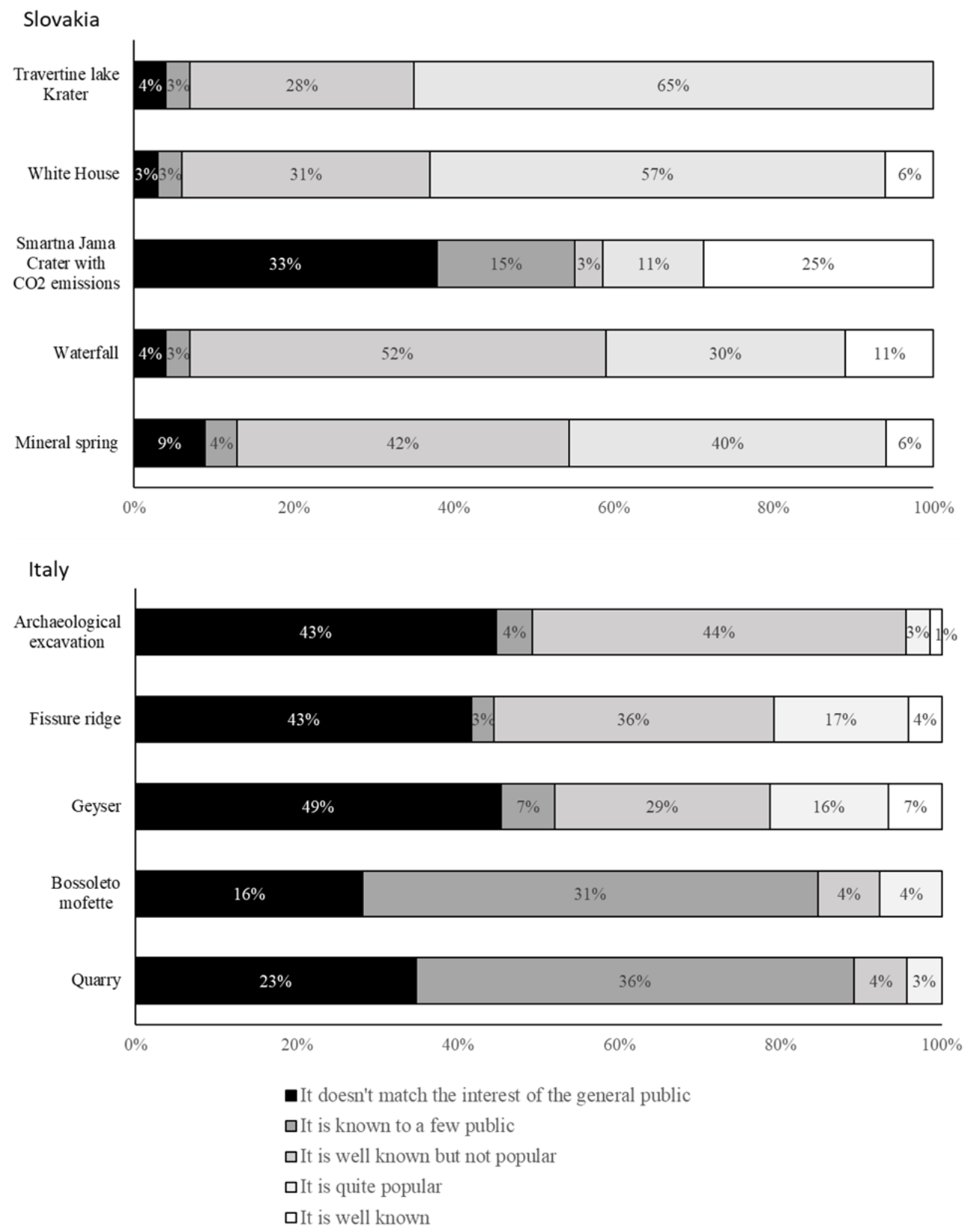

Figure 14. Perception of attractiveness of geological features by the respondents in Kúpele Vyšné Ružbachy in Slovakia $(\mathrm{N}=100)$ and San Giovanni spa in Italy $(\mathrm{N}=71)$. 


\subsection{Assessment of Local Services and Information Sources by Respondents}

Regarding the means of transport used to access the spa sites (Figure 15), respondents in Slovakia considered the improvement of local transport (54\%) and biking routes $(63 \%)$ to be very important. In Italy, improving local public transport was also very important (for $72 \%$ of respondents) even as compared to the Slovaks $(\alpha<0.05)$, though hiking trails were also considered very important to improve (for $71 \%$ respondents; $\alpha<0.005$ ). To a lesser extent, roads and biking routes were also seen as deserving of improvement.

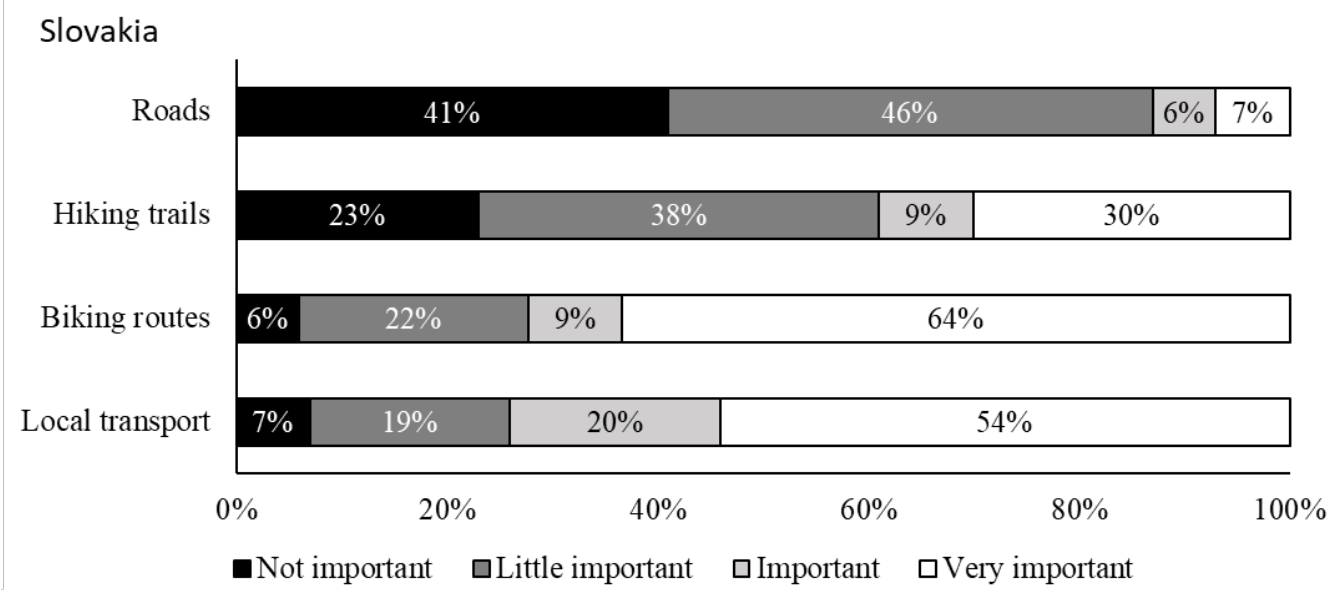

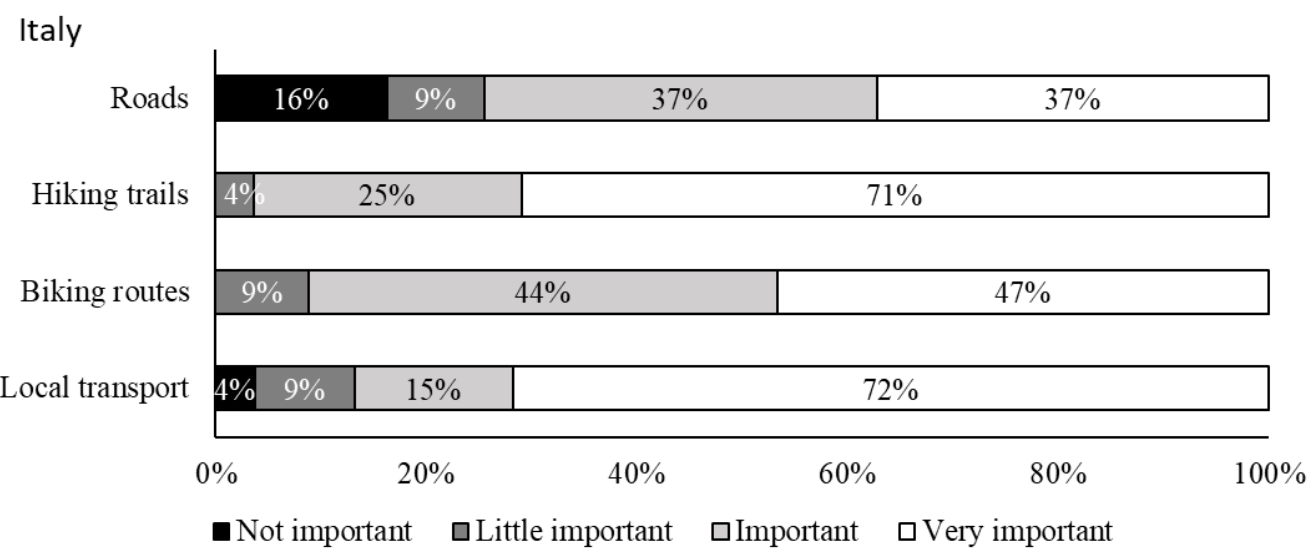

Figure 15. The level of importance associated with improving the quality of different means of travel, in Slovakia $(\mathrm{N}=100)$ and in Italy $(\mathrm{N}=71)$. The question allowed for multiple answers.

Regarding the services connected to knowledge of the territory, in both Slovakia and Italy informative panels (for $80 \%$ and 95\% respondents, respectively) and leaflets in tourist places (for 93\% respondents in both countries), were valued as the most important means of cultural and geological information. Also important are guided excursions in both countries, while apps for mobile devices seem to be more appreciated by Italians respondents, with $47 \%$ considering them very important, compared to $25 \%$ of those in Slovakia $(\alpha<0.005)$. Scenic flights or virtual tours are in general less important (Figure 16).

The results, as summarized in Figure 17, suggest that potential geo-tourists have multi-layered backgrounds, and that they may be expected to have a variety of purposes for visiting geothermal spas. Despite their initial motivations for visiting, however, it is clear that there is a general receptiveness among tourists to information and experiences that might enrich their knowledge of abiotic nature. Their statements on tourism development indicate that there is an untapped potential to better customize the current tourist offerings, and extend them with new and interesting geo-attractions. 


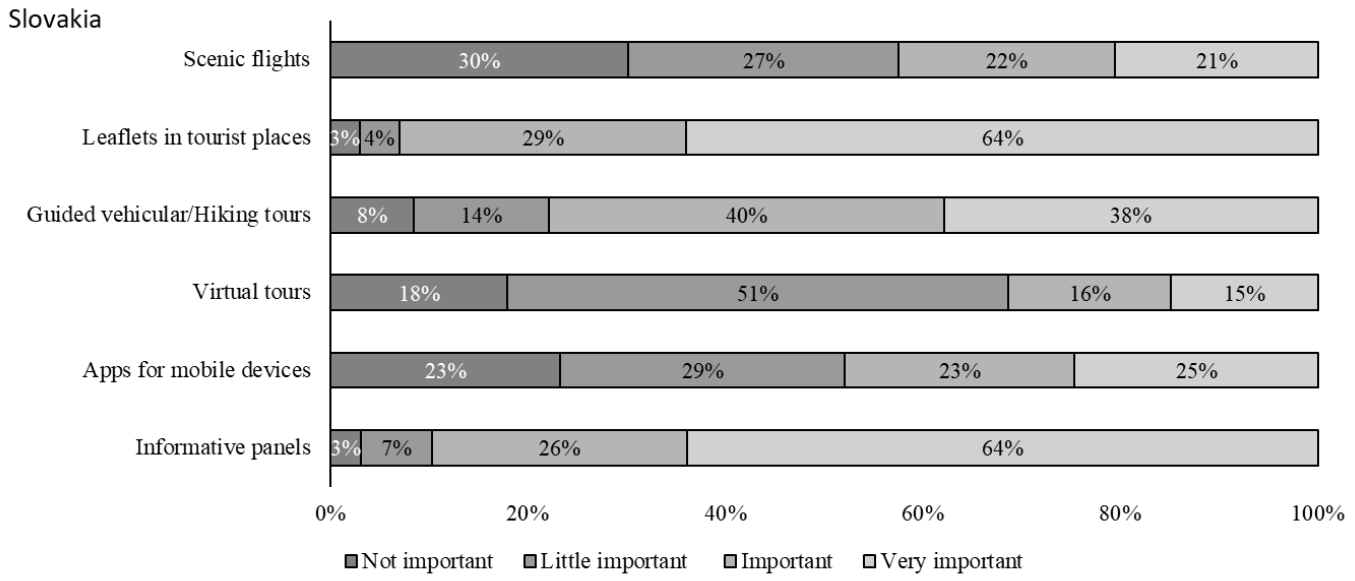

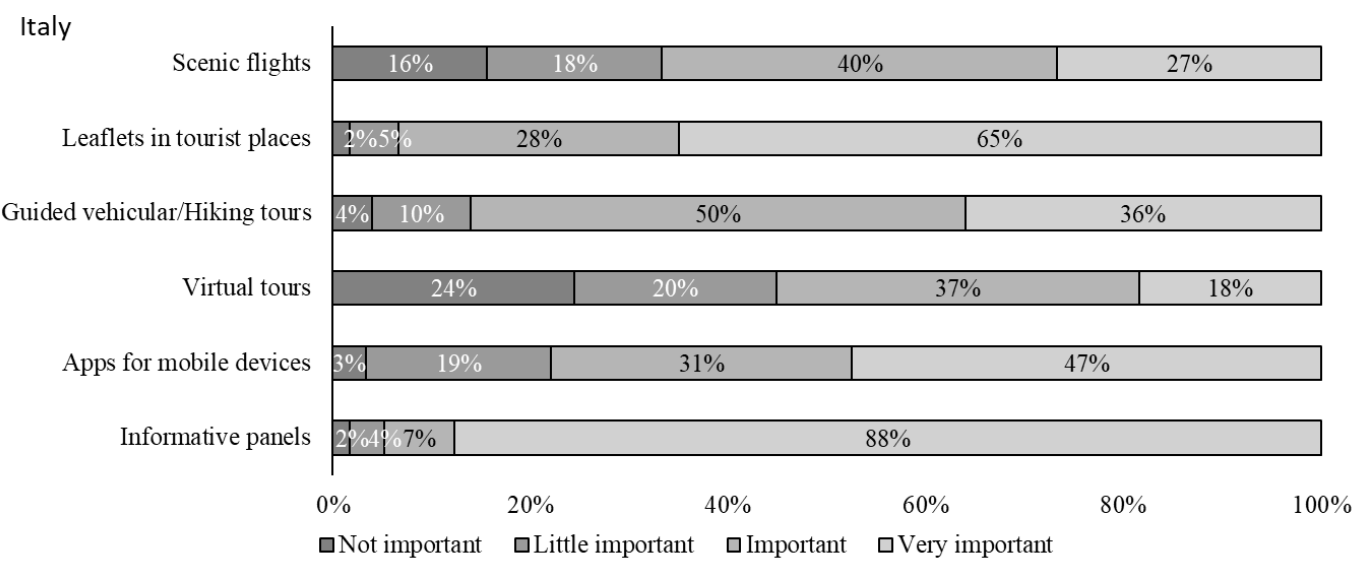

Figure 16. Percentage of responses gauging the level of importance of various means for the improvement of tourism information in Slovakia $(\mathrm{N}=100)$ and in Italy $(\mathrm{N}=71)$. The question allowed for multiple answers.

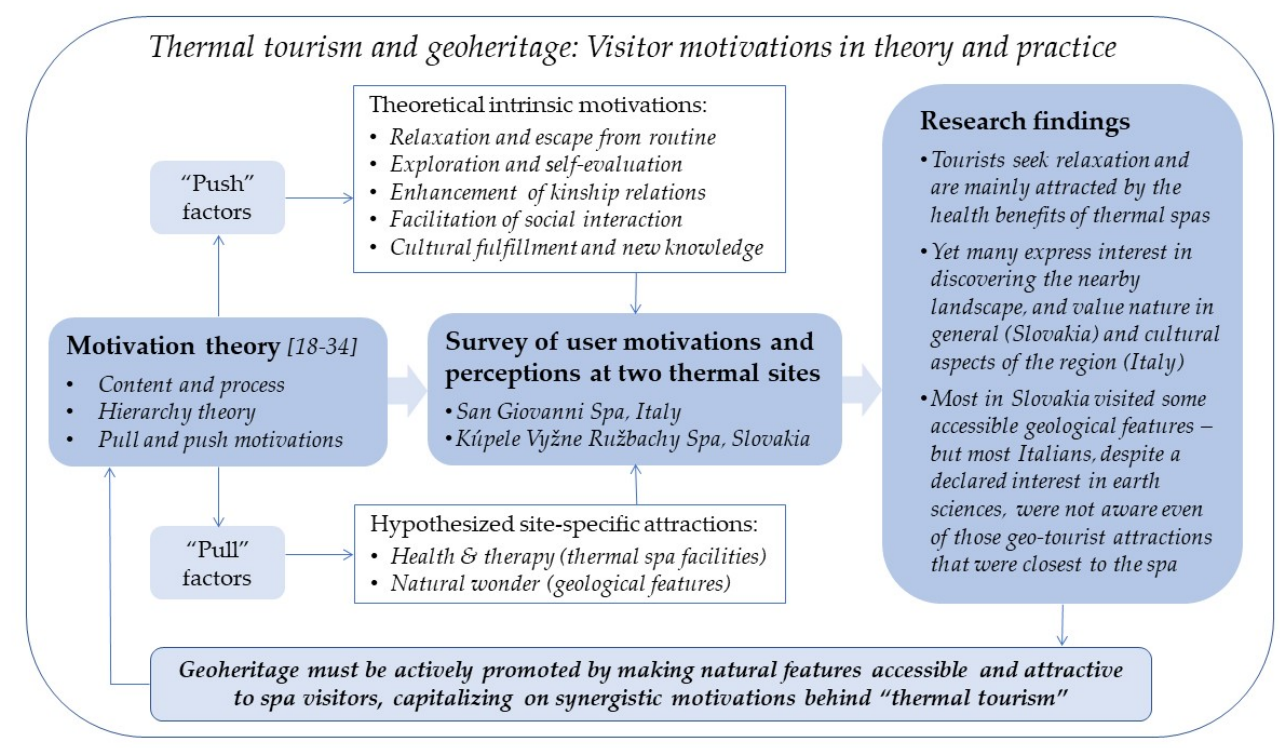

Figure 17. Graphical summary of the research query and its responses.

\section{Discussion}

According to the European Historical Thermal Town Association in 2010, European "health tourism" has been increasing in prominence, mainly stirring the idea of healing, therapy, and a 
healthy, disciplined way of living that is more respectful of one's own body [65]. In Slovakia, spa tourism is considered one of the most important types of tourism [66], considering also the recent European Directive on Cross-Border Healthcare [67] that has given new impetus to health-related tourism across Europe (since according to the Directive, there should be free access to treatment in the Community space for all EU citizens). Since hydrotherapy has been widely promoted, big-city hotels and single-establishment spas, or "health resorts" — even those without a connection to natural thermal springs or to the medical establishment-have been funded in many European towns [65]. This might be considered a threat for the spas located in the natural spring sites themselves, which are usually far from the main cities. For instance, the Vyšné Ružbachy spa examined in this study is located in the attractive area of Spišská Magura Range, close to the Tatra Mountains [68]. The Spiš Region is very famous at a national level for its educational and aesthetic value, with wonderful panoramic views toward the Tatra Mountains $[13,35,69,70]$. The area is also relevant for its cultural heritage, history, ethnography, etc. as is testified to by nearby UNESCO monuments [68,71]. San Giovanni spa is in the heart of the picturesque Tuscan landscape, characterized by gentle rolling hills covered with woodlands and wheat fields [72,73]. Moreover, both sites are located at a distance of about $100 \mathrm{~km}$ from the closest large towns.

It may be reasonably assumed that the extent to which geotourism can complement other types of tourism (such as those centered on health and wellness) depends on the level of awareness that non-expert tourists have of the relevant co-located geological attractions, and how accessible and visible these features are $[74,75]$. This assumption triggered the current study, which paints a picture of the type of tourists who are visiting thermal spas in two different regions, and their potential interest in knowing more about nearby natural features of geological interest-with the goal of identifying the possible linkages between health or wellness tourism and geotourism [76,77].

The analysis of the survey results has demonstrated that many tourists show a positive interest toward Earth science in general, and in addition toward a set of related topics that are linked to the specific geographical territory — such as its history, geology and landforms, flora and fauna, and particularly in Italy its local food and agriculture which are symbols of the local landscape and traditions. The attention of tourists to "what is around" is also confirmed by the high percentage of respondents who reported actually seeing geomorphological features in the landscape while exploring around or travelling to the spa, especially those features that are easily recognized and visible.

Among the theories that have been put forward to analyze the motivations that drive tourists to particular places, we find the previously-mentioned "push and pull" motivation theories [27,28] to be especially pertinent for understanding the special case of thermal spa tourism. Despite indications that there are some important differences between the type of visitors at San Giovanni spa and those at Kúpele Vyšné Ružbachy (findings which complement and confirm previous assessments of the latter spa) $[70,78]$, tourists in both cases respond not only to their own personal needs but also to diverse interpersonal needs [26].

The "pushing" factors for tourists in both spas include the need to relax and to escape from routine, as illustrated firstly in Slovakia. Kúpele Vyšné Ružbachy spa is mostly visited by two different groups: (1) young people, including students, who want to spend some free time in the peaceful and relatively affordable spa area, and (2) elderly people, who are mostly retired and come to the spa because of their health problems. In addition, the spa represents a place to meet people and stay with family and friends. In contrast, in Italy most of the tourists at San Giovanni spa are between 36 and 55 years old and are mostly searching for relaxation, though many are also motivated by the chance to spend some time with their family, as well as to explore new places-and to satisfy their sense of wonder.

This latter motivation-the desire to discover unique attractions in different corners of the world-is one whose fulfillment depends entirely on the "pull" of the location in question. In this case the pulling factors can be considered to include the attractiveness of the spa facilities and the atmosphere that they can offer. The question, however, is to what extent the unique geological features around the spa represent a pull for tourists who are already visiting. 
Regardless of the duration of their stay, visitors to both spas reported taking some time for other purposes-such as hiking (in Slovakia), visiting cultural attractions (in Italy), and even exploiting the natural richness of the respective region. Nevertheless, visitors seemed not to pay too much attention to the geological features of the area surrounding the spa. All Slovak respondents recognized the most significant geological features (such as the travertine lake krater and the White House) at the spa, well known and easily accessible. However most did not visit the other features, arguably of no less interest, and indeed among the Italian respondents (who generally declared a high level of interest in earth science), only a small group noticed some of the most easily visible geological elements-such as the geyser and the fissure ridge, which are located within the spa area in the front garden. Surprisingly, half of all respondents considered these elements inaccessible (even though they are easily accessed from the spa). Again, we would suggest that this is largely due to the absence of signs or panels in the spa area, indicating or explaining the geological elements or their geographical context. At the same time, however, these 'geotouristic' elements - which were seen by respondents in photos included in the questionnaire-were not considered to be especially attractive to the general public, and most of them attractive only for a small niche of tourists.

Despite the varying degree to which visitors' attention was drawn to these natural features, we can confirm that Slovak tourists, aside from their specific interest in nature, generally demonstrated a dynamic and pragmatic approach, exploring the surroundings and visiting geological elements near the spa. Italians, in contrast, limited their explorations and the majority either did not see any geological feature at all or saw only one, which was most visible. This is likely attributable to a combination of reasons, including the low priority of the spa to publicize these sites and the subsequent lack of knowledge of those features among visitors. In fact, there is considerable evidence that even when a particular natural feature has undeniable appeal to the public, its special qualities are not appreciated unless these qualities are actively brought to the attention of tourists $[35,36,78,79]$.

This may even be the case when the features in question are of great interest to visitors who are especially interested in earth sciences; they do not attract many visitors simply because the information presented to the public about them is not adequate. In fact, several studies on tourist interest in environmental amenities have shown that whether their value is primarily naturalistic, historical or cultural, the creation of awareness toward these amenities is the determinant force in tourism development [80-83]. Nevertheless, in this case large numbers of tourists in both groups agreed on the necessity of improving the network of hiking trails, which hopefully would give tourists the possibility to enjoy and get to know more about the surroundings.

In summary, the attractiveness of such areas is dependent not only on their visual aesthetics and accessibility, but also on the capacity of tourism service providers to bring their aesthetic and informational value to the attention of interested visitors [84]. Clearly, a tourism offering that is more sensitive to the promotion of natural attractions in the local territory has a high potential to attract more tourists [85,86] —and in both of the cases examined here, the successful promotion of the remarkable geological features that may be found in the immediate vicinity of the spa would represent a strong "pulling" motivation for attracting tourists in the long term. This potential could become especially formidable by targeting not only overnight guests of the spa hotel, but also the large numbers of daily visitors-who according to our survey, demonstrate a positive attitude toward discovering diverse aspects of the territory, and enjoying the synergistic possibilities of "thermal tourism".

The most important means of doing this, according to the bulk of respondents, are leaflets, informational panels, guided tours and applications on mobile devices (especially for young visitors, and particularly among Italians).

Despite the limitation of the study to only two spas, the results may be seen as a complement to the growing number of empirical discoveries $[87,88]$ which have shown that, along with the internet and the increasingly wide array of smartphone applications that are designed to facilitate access and information flow, word-of-mouth communication and personal experience is still one of the most important forms of information transfer. 
Finally, respondents at both spas identified a number of aspects that could be improved for a better and more varied tourism offering: (1) "Green" accessibility to the areas by improving public transport, biking routes and hiking trails; (2) Access to information about geological elements that they are not able to identify on their own, through onsite materials such as leaflets and explanatory panels. These suggestions would form the basis for a tourist offering that is more sensitive to the tourist, offering additional services such as guided tours, addressed not only to a niche of experts, but also to any other interested tourist.

\section{Conclusions}

This study, even with its limited focus on two individual thermal tourism sites, has offered evidence that tourists at spas are primarily attracted by self-centered concerns such as the need for relaxation and escape from routine, and to a lesser extent by the opportunity to spend time with their friends and families. However, this does not mean they are not interested in knowing more about the landscape and the scientific value of the nearby geological features. In fact, they would appreciate more information about nature in general (especially in Slovakia), and about cultural aspects of the region (especially in Italy). While actual behavior in Slovakia was relatively consistent with this attitude, with many respondents confirming that they had hiked and visited all the most accessible geological features of the area, Italians' behavior was somewhat different: Most of them did not see even the most accessible geological features-likely because they were simply more attracted by the pools, or because they did not know about the existence of such features due to the absence of information within the spa.

One highly recommended remedy for this would be the improvement of "green" accessibility to the spa and its natural surroundings, through means such as public transportation, hiking trails (in Italy) and biking routes, and "accessibility" to scientific knowledge related to geotourism features in the form of explanatory panels, leaflets or apps for mobile devices. These recommendations would increase tourism diversity and service quality, highlighting the geological elements of cultural significance and worthy of geotourism promotion, capitalizing on a fuller vision of the spa attraction.

In conclusion, we may offer a qualified "affirmative" answer to the question raised initially: Even though many spa tourists do not take advantage of nearby sites geo-touristic value, they indeed would do so to a greater extent if this value was sufficiently communicated. Conducting surveys of this type, aimed at better understanding tourist preferences and assessing potential geotourism attractions, is thus an important complementary element in the creation of new tourist products.

Undoubtedly, an advantage of this type of research is that the most important conclusions are based on the analysis of statements of respondents who actually visited spas and used their services. Conducting questionnaires in this fashion can elicit reliable answers from people who were deliberately selected for this research, and therefore a relatively small sample can be representative. However, this approach also has its disadvantages; namely that in order to reach a sufficient cross-section of spa visitors it was necessary to limit the data collection to particular time periods (i.e., sunny days during tourist season). In future research it would be valuable to be compare tourists' preferences regarding geosites with expert assessment of these sites' intrinsic value, in order to paint a more holistic picture of geotourism and its potential to truly enrich the travel experience.

Supplementary Materials: The following are available online at http://www.mdpi.com/2079-9276/9/5/58/s1.

Author Contributions: Conceptualization, A.C., F.U., D.P. and A.R.; methodology, A.C. and F.U.; validation, A.C., F.U.; formal analysis, A.Ch and F.U.; investigation, A.C. and F.U.; resources, A.C. and F.U.; data curation, A.C., F.U. and D.P.; writing—original draft preparation, A.C. and F.U.; writing—review \& editing, D.P.; visualization, A.C. and F.U.; supervision, A.C., A.R.; project administration, A.C.; funding acquisition, A.C. All authors have read and agreed to the published version of the manuscript.

Funding: This research was funded by Pedagogical University of Krakow, grant number BS-652/G/2019, BN-173/NŚiP/2020 and BN. 3115-110/2020/RN. 
Acknowledgments: The authors thank the directors of the two spa, Kúpele Vyšné Ružbachy and Terme San Giovanni, for allowing this research inside their facilities. The authors are grateful for four anonymous reviewers for their thorough reviews and constructive comments. This work was supported by the Pedagogical University of Krakow under Grant No BS-652/G/2019, BN-173/NŚiP/2020 and BN. 3115-110/2020/RN.

Conflicts of Interest: The authors whose names are listed immediately below certify that they have NO affiliations with or involvement in any organization or entity with any financial interest (such as honoraria; educational grants; participation in speakers' bureaus; membership, employment, consultancies, stock ownership, or other equity interest; and expert testimony or patent-licensing arrangements), or non-financial interest (such as personal or professional relationships, affiliations, knowledge or beliefs) in the subject matter or materials discussed in this manuscript.

\section{References}

1. IRPET. Rapporto Sul Turismo in Toscana. La Congiuntura. 2014. Available online: http://www.irpet.it/ storage/eventoallegato/1599_Rapporto_Turismo_2014.pdf (accessed on 15 April 2020).

2. De Carlo, A. Towards Alternative Forms of Tourism. The Polish Experience. In Tourism and Tourist Promotion Around the World: A Linguistic and Socio Cultural Perspective; Manca, E., Bianchi, F., Eds.; Università del Salento-Coordinamento SIBA: Lecce, Italy, 2013; pp. 31-46.

3. Hose, T.A. Selling the story of Britain's Stone. Environ. Interpret. 1995, 10, 16-17.

4. Hose, T.A.; Marković, S.B.; Komac, B.; Zorn, M. Geotourism-A Short Introduction. Acta Geogr. Slov. 2011, 51, 339-342. [CrossRef]

5. Newsome, D.; Dowling, R.K. Geotourism. The Tourism of Geology and Landscape; Goodfellow Publishers Limited: Oxford, UK, 2010; ISBN 978-1-906884-09-3.

6. Ólafsdóttir, R. Geotourism. Geosciences 2018, 9, 48. [CrossRef]

7. Hose, T.A. 3G's for Modern Geotourism. Geoheritage 2012, 4, 7-24. [CrossRef]

8. Erfurt-Cooper, P. The importance of natural geothermal resources in tourism. In Proceedings of the World Geothermal Congres, Bali, Indonesia, 25-29 April 2010; Available online: https://www.geothermal-energy. org/pdf/IGAstandard/WGC/2010/3318.pdf (accessed on 15 April 2020).

9. Gałaś, A.; Paulo, A.; Gaidzik, K.; Zavala, B.; Kalicki, T.; Churata, D.; Gałaś, S.; Marino, J. Geosites and Geoturistic Attractions Proposed for the Project Geopark Colca and Volcanoes of Andagua, Peru. Geoheritage 2018, 10, 707-729. [CrossRef]

10. Radwanek-Bąk, B. Selected Geosites and Geotourist Objects in Colca Canyon and its Vicinity (Southern Peru). Geotourism 2008, 15, 3-12. [CrossRef]

11. Kazanc1, N. Geological Background and Three Vulnerable Geosites of the Kızılcahamam-Çamlıdere Geopark Project in Ankara, Turkey. Geoheritage 2012, 4, 249-261. [CrossRef]

12. Miljković, Đ.; Božić, S.; Miljković, L.; Marković, S.B.; Lukić, T.; Jovanović, D.; Bjelajac, D.; Vasiljević, Đ.A.; Vujičić, M.D.; Ristanović, B. Geosite Assessment Using Three Different Methods; a Comparative Study of the Krupaja and the Žagubica Springs-Hydrological Heritage of Serbia. Open Geosci. 2018, 10, 192-208. [CrossRef]

13. Štrba, L. Identification and Evaluation of Geosites along Existing Tourist Trail as a Primary Step of Geotourism Development: Case Study from the Spiš Region (Slovakia). GeoJ. Tour. Geosites 2015, 16, 127-141.

14. Dowling, R.K.; Newsome, D. Geotourism; Routledge: Abingdon, UK, 2006; ISBN 9780750662154.

15. Hose, T.A. Towards a history of geotourism: Definitions, antecedents and the future. Geol. Soc. Lond. Spec. Publ. 2008, 300, 37-60. [CrossRef]

16. Mucivuna, V.C.; Reynard, E.; da Garcia, M.G.M. Geomorphosites Assessment Methods: Comparative Analysis and Typology. Geoheritage 2019, 11, 1799-1815. [CrossRef]

17. ISPRA. Guida Alla Compilazione Della Scheda per L'Inventario Nazionale dei Geositi. 2002. Available online: http://sgi.isprambiente.it/GeositiWeb/public/GuidaCompilazioneSchedaGeositi.pdf (accessed on 20 April 2020).

18. Kozak, M.; Decrop, A. Handbook of Tourist Behavior: Theory \& Practice; Routledge, Business \& Economics: New York, NY, USA, 2009; ISBN 978-0-415-99360-9.

19. Allan, M. Toward a Better Understanding of Motivations for a Geotourism Experience: A Self-Determination Theory Perspective. 2011. Available online: https://ro.ecu.edu.au/theses/438 (accessed on 20 April 2020).

20. Maslow, A.H. A Theory of Human Motivation. Psychol. Rev. 1943, 50, 370-396. [CrossRef] 
21. Locke, E.A.; Latham, G.P.; Smith, K.J.; Wood, R.E. A Theory of Goal Setting E Task Performance; Pearson College Div: London, UK, 1990; ISBN 10: 0139131388.

22. Vroom, V.H. Work and Motivation; Wiley: New York, NY, USA, 1964; ISBN 10: 0471912050.

23. Pearce, D.G. Tourist Time-Budget. Ann. Tour. Res. 1988, 15, 106-121. [CrossRef]

24. Crompton, J.L. Motivations for Pleasure Vacation. Ann. Tour. Res. 1979, 6, 408-424. [CrossRef]

25. Iso-Ahola, S.E.; Allen, J.R. The dynamics of Leisure Motivation: The Effects of Outcome on Leisure Needs. Res. Q. Exerc. Sport 1982, 53, 141-149. [CrossRef]

26. Yousaf, A.; Amin, I.; Santos, C.; Antonio, J. Tourist's Motivations to Travel: A Theoretical Perspective on the Existing Literature. Tour. Hosp. Manag. 2018, 24, 197-211. [CrossRef]

27. Dann, G.M. Anomie, Ego-Enhancement and Tourism. Ann. Tour. Res. 1977, 4, 184-194. [CrossRef]

28. Dann, G. Tourist Behavior as Controlled Freedom. In Tourism Research: Building a Better Industry, Proceedings of the Australian Tourism and Hospitality Research Conference, Sydney, Australia, 6-9 July 1997; Bureau of Tourism Research: Canberra, Australia, 1997; p. 244.

29. Bashar, A.M.; Al-Haj, M.; Ahmad, P.M.S. An Analysis of Push and Pull Travel Motivations of Foreign Tourists to Jordan. Int. J. Bus. Manag. 2010, 5, 41-50. [CrossRef]

30. Seebaluck, N.V.; Munhurrun, P.R.; Naidoo, P.; Rughoonauth, P. An analysis of the Push and Pull Motives for Choosing Mauritius as "the" Wedding Destination. Procedia Soc. Behav. Sci. 2015, 175, 201-209. [CrossRef]

31. Gartner, W.C. Image Formation Process. J. Travel Tour. Mark. 1993, 2, 191-215. [CrossRef]

32. Dann, G.M. Greenspeak: An Analysis of the Language of Eco-Tourism. Prog. Tour. Hosp. Res. 1996, 2, 247-259. [CrossRef]

33. Baloglu, S.; Brinberg, D. Affective Images of Tourism Destinations. J. Travel Res. 1997, 35, 11-15. [CrossRef]

34. Yoon, Y.; Uysal, M. An Examination of the Effects of Motivation and Satisfaction on Destination Loyalty: A Structural Model. Tour. Manag. 2005, 26, 45-56. [CrossRef]

35. Chrobak, A.; Ugolini, F.; Pearlmutter, D. Examining the Geotourist Value of Landscape Features. Case Study: The Vyšné Ružbachy in the Spiš Region, NE Slovakia. In Proceedings of the GEOTOUR 2016, Florence, Italy, 18-20 October 2016; pp. 178-187.

36. Ugolini, F.; Chrobak, A.; Pearlmutter, D.; Raschi, A. Examining the Tourism Value of Geological Landscape Features: The Case of Terme San Giovanni in the Siena clay lands of Tuscany. Acta Geoturistica 2016, 7, $22-35$.

37. Urbánek, J.; Beták, J.; Jakál, J.; Lacika, J.; Novotný, J. Regional Geomorphological Division of Slovakia: Old Problem in New Perspectives in Slovak Geography at the Beginning of the 21st Century. Geogr. Slovaca 2009, 26, 237-259.

38. Gross, P. Litostratigrafia Západných Karpát: Paleogén-Podtatranská Skupina; Štatny Geologický Ústav Dionýza Štúra: Bratislava, Slovakia, 2008; ISBN 978-80-89343-20-1.

39. Janočko, J.; Gross, P.; Jacko, S.J.; Buček, S.; Karoli, S.; Žec, B.; Polák, M.; Rakús, M.; Potfaj, M.; Halouzka, R. Geologická Mapa Spišskej Magury, 1:50 000; Štatny Geologický Ústav Dionýza Štúra: Bratislava, Slovakia, 2000; ISBN 80-88974-15-1.

40. Janočko, J.; Gross, P.; Polák, M.; Potfaj, M.; Jacko, S.; Rakús, M.; Halouzka, R.; Jetel, J.; Petro, L'.; Kubeš, P. Vysvetlivky Ku Geologickej Mape Spišskej Magury 1: 50 000; Štatny Geologický Ústav Dionýza Štúra: Bratislava, Slovakia, 2000; ISBN 80-88974-27-5.

41. Gradziński, M.; Duliński, M.; Hercman, H.; Stworzewicz, E.; Holubek, P.; Rajnoga, P.; Wróblewski, W.; Kováčová, M. Facies and Age of Travertines From Spiš and Liptov Regions (Slovakia)_Preliminary Results. Slovenský Kras 2008, 46, 31-40.

42. Gradziński, M.; Wróblewski, W.; Bella, P. Cenozoic freshwater carbonates of the central carpathians (Slovakia): Facies, environments, hydrological control and depositional history. In Guide to Field Trip B7, Proceedings of the 31st IAS Meeting of Sedimentology, Kraków, Poland, 22-25 June 2015; Polish Geological Society: Kraków, Poland, 2015; pp. 217-245.

43. Martini, I.P.; Sagri, M. Tectono-Sedimentary Characteristics of Late Miocene-Quaternary Extensional Basins of the Northern Apennines. Earth Sci. Rev. 1993, 34, 197-233. [CrossRef]

44. Bertini, G.; Cameli, G.M.; Costantini, A.; Decandia, F.A.; Di Filippo, M.; Dini, I.; Elter, F.M.; Lazzarotto, A.; Liotta, D.; Pandeli, E.; et al. Struttura Geologica Fra i Monti Di Campiglia e Rapolano Terme (Toscana Meridionale): Stato Attuale Delle Conoscenze e Problematiche. Studi Geol. Camerti 1991, 155-178. [CrossRef] 
45. Bambini, A.M.; Brogi, A.; Cornamusini, G.; Costantini, A.; Foresi, L.M.; Lazzarotto, A. Geologia Dell'area Di Rapolano Terme in Provincia Di Siena (Appennino Settentrionale). Ital. J. Geosci. 2010, 129, 457-495. [CrossRef]

46. Brogi, A. Faults Linkage, Damage Rocks and Hydrothermal Fluid Circulation: Tectonic Interpretation of the Rapolano Terme Travertines (Southern Tuscany, Italy) in the Context of Northern Apennines Neogene-Quaternary Extension. Eclogae Geol. Helv. 2004, 97, 307-320. [CrossRef]

47. Brogi, A.; Capezzuoli, E.R.A.; Branca, M.; Voltaggio, M. Studying Travertines for Neotectonics Investigations: Middle-Late Pleistocene Syn-Tectonic Travertine Deposition at Serre Di Rapolano (Northern Apennines, Italy). Int. J. Earth Sci. 2010, 99, 1383-1398. [CrossRef]

48. Guerra, M.; Raschi, A. Field Trip Guide Book D03-Field Sight near Rapolano Terme (Siena, Tuscany). Relationship between Tectonics and Fluid Circulation. In Proceedings of the 32nd International Geological Congress, Florence, Italy, 20-28 August 2004; pp. 1-14.

49. Brogi, A.; Capezzuoli, E. Travertine Deposition and Faulting: The Fault-Related Travertine Fissure-Ridge at Terme S. Giovanni, Rapolano Terme (Italy). Int. J. Earth Sci. 2009, 98, 931-947. [CrossRef]

50. Guo, L.; Riding, R. Hot-Spring Travertine Facies and Sequences, Late Pleistocene, Rapolano Terme, Italy. Sedimentology 1998, 45, 163-180. [CrossRef]

51. Kies, A.; Hengesch, O.; Tosheva, Z.; Raschi, A.; Pfanz, H. Diurnal $\mathrm{CO}_{2}-$ Cycles and Temperature Regimes in a Natural $\mathrm{CO}_{2}$ Gas Lake. Int. J. Greenh. Gas Control 2015, 37, 142-145. [CrossRef]

52. Fontani and Costantini. 2007. Available online: https://www.regione.toscana.it/-/conoscere-i-geositi (accessed on 20 April 2020).

53. Hynie, O. Hydrogeologie ČSSR, II, Minerálni Vody; Nakladatelstvi Československé Akademie Véd: Prague, Czech Republic, 1963.

54. Fendeková, M. Zdroje Minerálnych Vôd v Oblasti Vyšných Ružbach a Možnosti Získania Záložného Zdroja, Unpublished Report; Hydrofen: Bratislava, Slovakia, 2002.

55. Košt'álik, J. Travertíny vo Vyšných Ružbachoch, ich Charakteristika a Stratigrafia. Zborník Pedagogickej Fakulty v Prešove 1982, 19, 231-252.

56. Košt'álik, J. Travertíny Svedkovia Geologickej Minulosti a Súčasnosti a ich Genéza a Chronostratigrafia. Geografia 2006, 2, 59-65.

57. Porubský, A. Vyšné Ružbachy-Najvýdatnejší Areál Minerálnych Vôd na Slovensku. Geografický Časopis 1977, 29, 19-31.

58. Potočná, E. Vyšné Ružbachy. Kúpelná Obec; Region Poprad S.R.O.: Poprad, Slovakia, 2007.

59. Selvi, F.; Bettarini, I. Geothermal Biotopes in Central-Western Italy from a Botanical Point of View; Cambridge University Press: Cambridge, UK, 1999.

60. Carrara, C.; Ciuffarella, L.; Paganin, G. Inquadramento Geomorfologico e Climaticoambientale dei Travertini di Rapolano Terme (SI). Il Quaternario 1998, 11, 319-329.

61. Kamata, H.; Misui, Y. The Difference of Japanese Spa Tourists Motivation in Weekends and Weekdays. Procedia Soc. Behav. Sci. 2015, 175, 210-218. [CrossRef]

62. Lehman, E.L. Nonparametrics Statistical Methods Based on Ranks; Springer: New York, NY, USA, 1975; ISBN 9780387352121.

63. Nikulin, M.S. Chi-squared Test for Normality. In Proceedings of the International Vilnius Conference on Probability Theory and Mathematical Statistics, Vilnius, Lithuania, 2-6 July 2018; Volume 2, pp. 119-122.

64. Corder, G.W.; Foreman, D.I. Nonparametric Statistics: A Step-by-Step Approach; Wiley: New York, NY, USA, 2014; ISBN 10: 1118840313.

65. European Historical Thermal Town Association (EHTTA). European Route of Thermal Heritage and Thermal Towns. 2010. Available online: http://ehtta.eu/portal/wp-content/uploads/2010/09/EHTTA_european_route. pdf (accessed on 20 April 2020).

66. Kasagranda, A.; Gurňák, D. Spa and Wellness Tourism in Slovakia (a geographical analysis). Czech J. Tour. 2017, 6, 27-53. [CrossRef]

67. Union, E. Directive 2011/24/EU of the European Parliament and of the Council of 9 March 2011 on the Application of Patients' Rights in Cross-Border Healthcare. 2011. Available online: https://eur-lex.europa.eu/ legal-content/EN/TXT/PDF/?uri=CELEX:32011L0024\&from=EN (accessed on 20 April 2020).

68. Lacika, J. Spiš; Dajama: Bratislava, Slovakia, 1999. 
69. Chrobak, A. Geotourism Potential in the Podhale, Orava, Liptov and Spiš Regions (Southern Poland/Northern Slovakia). Acta Geoturistica 2015, 6, 1-10.

70. Chrobak, A. Geodiversity in the Spiš Region (Northern Slovakia/Southern Poland). In Dobrá Praxe v Udržitelnosti Cestovního Ruchu, Recenzovany Sbornik 5. Rocniku Conference; Zelenka, J., Ed.; Gaudeamus: Hradec Kralove, Czech Republic, 2015; pp. 6-16.

71. Bajcar, A. Multicultural Heritage as a Tourist Product in Selected Regions of Europe; Lambert Academic Publishing: Saarbrücken, Germany, 2018; ISBN 10:6139912636.

72. Agnoletti, M. Italian Historical Rural Landscapes; Springer: New York, NY, USA, 2013; ISBN 9789400753549.

73. Agnoletti, M.; Santoro, A. Rural Landscape Planning and Forest Management inTuscany (Italy). Forests 2018, 9, 473. [CrossRef]

74. Doktor, M.; Miśkiewicz, K.; Welc, E.M.; Mayer, W. Criteria of Geotourism Valorization Specified for Various Recipients. Geotourism 2015, 42-43, 25-38. [CrossRef]

75. Mikhailenko, A.V.; Ruban, D.A. Geo-Heritage Specific Visibility as an Important Parameter in Geo-Tourism Resource Evaluation. Geosciences 2019, 9, 146. [CrossRef]

76. Dryglas, D.; Różycki, P. European Spa Resorts in the Perception of Non-Commercial and Commercial Patients and Tourists: The Case Study of Poland. E-Rev. Tour. Res. 2016, 13, 382-400.

77. Dryglas, D.; Salamaga, M. Applying Destination Attribute Segmentation to Health Tourists: A Case Study of Polish Spa Resorts. J. Travel Tour. Mark. 2017, 34, 503-514. [CrossRef]

78. Chrobak, A. Analiza i Ocena Potencjału Geoturystycznego Podtatrza. Ph.D. Thesis, Uniwersytet Pedagogiczny w Krakowie, Krakow, Poland, 2018.

79. Štrba, L'. Analysis of Criteria Affecting Geosite Visits by General Public: A Case of Slovak (Geo)Tourists. Geoheritage 2019, 11, 291-300. [CrossRef]

80. Bański, J.; Wesołowska, M. Transformations in Housing Construction in Rural Areas of Poland's Lublin Region-Influence on the Spatial Settlement Structure and Landscape Aesthetics. Landsc. Urban Plan. 2010, 94, 116-126. [CrossRef]

81. Klepeis, P.; Gill, N.; Chisholm, L. Emerging Amenity Landscapes: Invasive Weeds and Land Subdivision in Rural Australia. Land Use Policy 2009, 26, 380-392. [CrossRef]

82. Lokocz, E.; Ryan, R.L.; Sadler, A.J. Motivations for Land Protection and Stewardship: Exploring Place Attachment and Rural Landscape Character in Massachusetts. Landsc. Urban Plan. 2011, 99, 65-76. [CrossRef]

83. Talandier, M. Mesurer l'impact des aménités naturelles, culturelles et environnementales sur le développement économique local. In Proceedings of the XLVIe Colloque de l'ASRDLF, Clermont-Ferrand, France, 6-8 July 2009.

84. Carneiro, M.J.; Lima, J.; Silva, A.L. Landscape and the Rural Tourism Experience: Identifying Key Elements, Addressing Potential, and Implications for the Future. J. Sustain. Tour. 2015, 23, 1217-1235. [CrossRef]

85. Girard, L.F.; Nijkamp, P. Cultural Tourism and Sustainable Local Development; Ashgate Publishing, Ltd.: Farnham, UK, 2009.

86. Corigliano, M.A.; Mottironi, C. 15 Wine and food tourism and place identity. In Place Branding: Connecting Tourist Experiences to Places; Taylor \& Francis: Milton Park, UK, 2019; p. 285.

87. Murphy, L.; Mascarado, G.; Benckendorff, P. Exploring Word-of-Mouth Influences on Travel Decisions: Friends and Relatives vs. Other Travellers. Int. J. Consum. Stud. 2007, 31, 517-527. [CrossRef]

88. Sotiriadis, M.D.; van Zyl, C. Electronic Word-of-Mouth and Online Reviews in Tourism Services: The Use of Twitter by Tourists. Electron. Commer. Res. 2013, 13, 103-124. [CrossRef]

(C) 2020 by the authors. Licensee MDPI, Basel, Switzerland. This article is an open access article distributed under the terms and conditions of the Creative Commons Attribution (CC BY) license (http://creativecommons.org/licenses/by/4.0/). 